Atmos. Chem. Phys., 19, 15691-15709, 2019

https://doi.org/10.5194/acp-19-15691-2019

(C) Author(s) 2019. This work is distributed under

the Creative Commons Attribution 4.0 License.

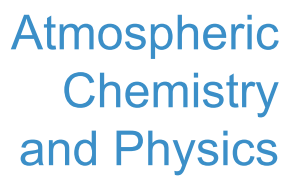

(c) (P)

\title{
Wintertime spatial distribution of ammonia and its emission sources in the Great Salt Lake region
}

\author{
Alexander Moravek ${ }^{1, a}$, Jennifer G. Murphy ${ }^{1}$, Amy Hrdina ${ }^{1, b}$, John C. Lin ${ }^{2}$, Christopher Pennell ${ }^{3}$, \\ Alessandro Franchin ${ }^{4,5}$, Ann M. Middlebrook ${ }^{5}$, Dorothy L. Fibiger ${ }^{4,5, \mathrm{c}}$, Caroline C. Womack ${ }^{4,5}$, \\ Erin E. McDuffie ${ }^{4,5,6, d}$, Randal Martin ${ }^{7}$, Kori Moore ${ }^{7, e}$, Munkhbayar Baasandorj ${ }^{2,3}$, and Steven S. Brown ${ }^{5,6}$ \\ ${ }^{1}$ Department of Chemistry, University of Toronto, Toronto, ON M5S 3H6, Canada \\ ${ }^{2}$ Department of Atmospheric Sciences, University of Utah, Salt Lake City, UT 84112, USA \\ ${ }^{3}$ Division of Air Quality, Utah Department of Environmental Quality, Salt Lake City, UT 84114, USA \\ ${ }^{4}$ Cooperative Institute for Research in Environmental Sciences (CIRES), University of Colorado Boulder, \\ Boulder, CO 80309, USA \\ ${ }^{5}$ Chemical Sciences Division, NOAA Earth System Research Laboratory (ESRL), Boulder, CO 80305, USA \\ ${ }^{6}$ Department of Chemistry, University of Colorado Boulder, Boulder, CO 80309, USA \\ ${ }^{7}$ Department of Civil and Environmental Engineering, Utah State University, Logan, UT 84322, USA \\ a now at: Department of Chemistry, York University, Toronto, ON M3J 1P3, Canada \\ ${ }^{b}$ now at: Department of Civil and Environmental Engineering, Massachusetts Institute of Technology, \\ Cambridge, MA 02139, USA \\ ${ }^{c}$ now at: California Air Resources Board, Sacramento, CA 95814, USA \\ ${ }^{d}$ now at: Department of Physics \& Atmospheric Science, Dalhousie University, Halifax, NS B2H 4R2, Canada \\ enow at: Space Dynamics Laboratory, Logan, UT 84341, USA
}

Correspondence: Alexander Moravek (amoravek@yorku.ca)

Received: 19 March 2019 - Discussion started: 21 May 2019

Revised: 19 November 2019 - Accepted: 27 November 2019 - Published: 20 December 2019

\begin{abstract}
Ammonium-containing aerosols are a major component of wintertime air pollution in many densely populated regions around the world. Especially in mountain basins, the formation of persistent cold-air pools (PCAPs) can enhance particulate matter with diameters less than $2.5 \mu \mathrm{m}\left(\mathrm{PM}_{2.5}\right)$ to levels above air quality standards. Under these conditions, $\mathrm{PM}_{2.5}$ in the Great Salt Lake region of northern Utah has been shown to be primarily composed of ammonium nitrate; however, its formation processes and sources of its precursors are not fully understood. Hence, it is key to understanding the emission sources of its gas phase precursor, ammonia $\left(\mathrm{NH}_{3}\right)$. To investigate the formation of ammonium nitrate, a suite of trace gases and aerosol composition were sampled from the NOAA Twin Otter aircraft during the Utah Winter Fine Particulate Study (UWFPS) in January and February 2017. $\mathrm{NH}_{3}$ was measured using a quantum cascade tunable infrared laser differential absorption spectrometer (QC-TILDAS), while aerosol composition, includ-
\end{abstract}

ing particulate ammonium $\left(p \mathrm{NH}_{4}\right)$, was measured with an aerosol mass spectrometer (AMS). The origin of the sampled air masses was investigated using the Stochastic TimeInverted Lagrangian Transport (STILT) model and combined with an $\mathrm{NH}_{3}$ emission inventory to obtain model-predicted $\mathrm{NH}_{x}\left(=\mathrm{NH}_{3}+p \mathrm{NH}_{4}\right)$ enhancements. Enhancements represent the increase in $\mathrm{NH}_{3}$ mixing ratios within the last $24 \mathrm{~h}$ due to emissions within the model footprint. Comparison of these $\mathrm{NH}_{x}$ enhancements with measured $\mathrm{NH}_{x}$ from the Twin Otter shows that modelled values are a factor of 1.6 to 4.4 lower for the three major valleys in the region. Among these, the underestimation is largest for Cache Valley, an area with intensive agricultural activities. We find that one explanation for the underestimation of wintertime emissions may be the seasonality factors applied to $\mathrm{NH}_{3}$ emissions from livestock. An investigation of inter-valley exchange revealed that transport of $\mathrm{NH}_{3}$ between major valleys was limited and $\mathrm{PM}_{2.5}$ in Salt Lake Valley (the most densely populated area in Utah) 
was not significantly impacted by $\mathrm{NH}_{3}$ from the agricultural areas in Cache Valley. We found that in Salt Lake Valley around two thirds of $\mathrm{NH}_{x}$ originated within the valley, while about $30 \%$ originated from mobile sources and $60 \%$ from area source emissions in the region. For Cache Valley, a large fraction of $\mathrm{NO}_{x}$ potentially leading to $\mathrm{PM}_{2.5}$ formation may not be locally emitted but mixed in from other counties.

\section{Introduction}

Ammonia $\left(\mathrm{NH}_{3}\right)$ is a key atmospheric pollutant, with significant impacts on air quality, climate and ecosystem nitrogen availability. As the most abundant base in the atmosphere, $\mathrm{NH}_{3}$ is an important precursor gas for secondary aerosol particle formation. As a result, ammonium-containing aerosols may comprise a significant amount of the particulate matter with a diameter of $2.5 \mu \mathrm{m}$ or less $\left(\mathrm{PM}_{2.5}\right)$ (Pozzer et al., 2017). High levels of $\mathrm{PM}_{2.5}$ impact human health by increasing the risk for stroke, heart disease, lung cancer, and both chronic and acute cause respiratory deceases (WHO, 2016). Especially in urban areas, where a mix of pollutants such as nitrogen oxides $\left(\mathrm{NO}_{x}\right)$, sulfur dioxide $\left(\mathrm{SO}_{2}\right)$ or volatile organic compounds (VOCs) are present in elevated concentrations alongside $\mathrm{NH}_{3}$, ammonium-containing aerosol can be a major source of $\mathrm{PM}_{2.5}$. For example, $\mathrm{NH}_{3}$ emitted from agricultural activities may be transported towards $\mathrm{NO}_{x}$-rich urban centres to form ammonium nitrate $\left(\mathrm{NH}_{4} \mathrm{NO}_{3}\right)$ or ammonium sulfate, $\left(\mathrm{NH}_{4}\right)_{2} \mathrm{SO}_{4}$, aerosols (e.g. Zhao et al., 2017). This illustrates the importance of the transport and meteorological conditions in mixing the precursors that lead to secondary particle formation.

During the winter season, cold temperatures in combination with high-pressure systems result in shallow boundary layers that trap and promote the build-up of pollutants near the surface, leading to enhanced secondary aerosol formation and winter smog. Episodes with strong atmospheric stability are referred to as persistent cold-air pool (PCAP) periods (Whiteman et al., 2014), typically featuring a temperature inversion below the height of the surrounding terrain. In addition, the topography of mountain basins promotes the evolution of strong PCAP periods and thereby the confinement of pollutants near the surface. Under these conditions, urban areas such as Salt Lake City frequently experience high $\mathrm{PM}_{2.5}$ concentrations. In the Great Salt Lake region in northern Utah, the $24 \mathrm{~h}$ US National Ambient Air Quality Standard (NAAQS) for $\mathrm{PM}_{2.5}\left(35 \mu \mathrm{g} \mathrm{m}^{-3}\right)$ is exceeded on average $18 \mathrm{~d}$ per winter (Silcox et al., 2012; Whiteman et al., 2014). Previous measurements made in the Salt Lake Valley (SLV; Kelly et al., 2013; Kuprov et al., 2014) and a recently published analysis of the Utah Winter Fine Particulate Study (UWFPS) aerosol composition (Franchin et al., 2018) agree that during PCAP periods up to $75 \%$ of wintertime $\mathrm{PM}_{2.5}$ is ammonium nitrate. The high amount of ammonium nitrate in aerosols in not surprising given that fact that the ammonia concentration measurements in the region are the highest within the US Ammonia Monitoring Network (AMoN) (AMoN, 2019).

To develop appropriate $\mathrm{PM}_{2.5}$ mitigation strategies in such areas where ammonium nitrate is high, it is essential to understand the mechanisms of local ammonium nitrate formation as well as the emission source of its precursor gases, $\mathrm{NO}_{x}$ and $\mathrm{NH}_{3}$. While emissions of $\mathrm{NO}_{x}$ are regulated, $\mathrm{NH}_{3}$ is not regulated as a criteria air pollutant (CAP) in the US. As a consequence, $\mathrm{NH}_{3}$ emissions are not reported by $\mathrm{NH}_{3}$ emitting industries or sectors to the same extent as other CAPs, resulting in higher uncertainties of $\mathrm{NH}_{3}$ emission estimates. In addition, observational networks for $\mathrm{NH}_{3}$ are sparse compared to those for $\mathrm{NO}_{x}$, which is in part related to the challenges in the measurement of $\mathrm{NH}_{3}$. Therefore, improving the understanding of $\mathrm{NH}_{3}$ sources is key to making reliable predictions of ammonium aerosol formation and finding the appropriate mitigation strategies for $\mathrm{PM}_{2.5}$.

To understand the sources of $\mathrm{NH}_{3}$ in the Great Salt Lake region, which are responsible for ammonium aerosol formation and high levels of $\mathrm{PM}_{2.5}$ in winter, we studied the spatial distribution of $\mathrm{NH}_{3}$ in the three mountain basins as part of the Utah Winter Fine Particulate Study (UWFPS, 2018). The spatial distribution of $\mathrm{NH}_{3}$ was measured from a Twin Otter aircraft and compared to $\mathrm{NH}_{3}$ measurements from several ground stations in the region. The main objectives of this study are to identify the sources of $\mathrm{NH}_{3}$ and the key emission sectors contributing to the regional formation of ammonium aerosol. To address these objectives, airborne measurements were compared to emission-inventory-based $\mathrm{NH}_{3}$ estimates. A footprint approach based on the Stochastic Time-Inverted Lagrangian Transport (STILT) model was used to estimate contributions from $\mathrm{NH}_{3}$ source regions, while the results are discussed for the three major valleys in the study region. Finally, the exchange of air masses between valleys is investigated and discussed in respect to its role for ammonium aerosol formation in the region.

\section{Methods}

\subsection{Study area and the Utah Winter Fine Particulate Study (UWFPS)}

The Utah Winter Fine Particulate Study was carried out in January and February 2017 in the Great Salt Lake region. The Great Salt Lake region is located in northern Utah in the US western Rocky Mountains, comprised of three major mountain valleys (Salt Lake Valley, Utah Valley, and Cache Valley) and the Great Salt Lake (Fig. 1a). Salt Lake City, the most populated urban area in Utah and part of the Salt Lake City metropolitan area (1.2 million inhabitants), is situated in the northern part of Salt Lake Valley bordering the Great Salt Lake. Cache Valley (125000 inhabitants), north of Salt Lake Valley, is separated by a branch of the Wasatch Range from the northern metropolitan area and is character- 
(a)

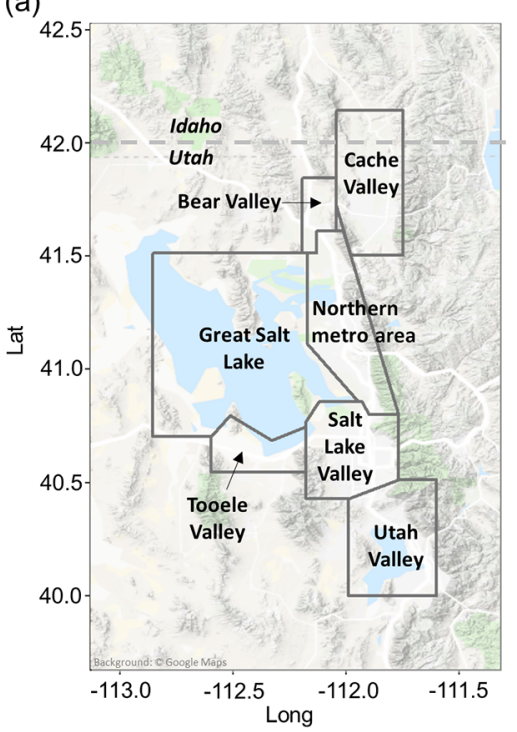

(b)

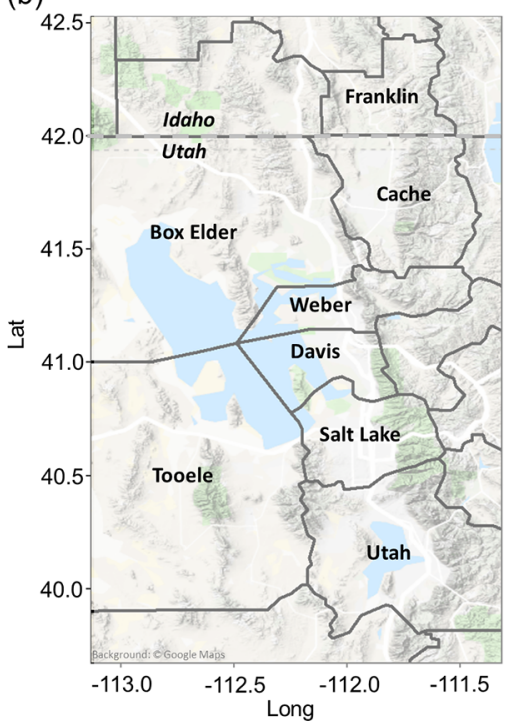

(c)

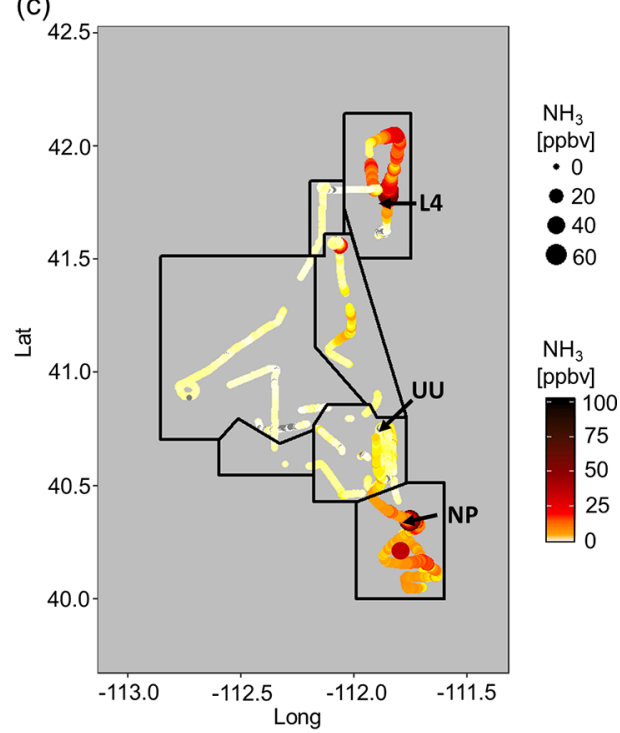

Figure 1. Overview of the study area: (a) outlines of sub-regions used for the analysis of Twin Otter measurements, (b) borders of counties which are part of the study area, and (c) typical $\mathrm{NH}_{3}$ mixing ratios measured from the Twin Otter combined from a northern and southern flight leg flight on 17 and 18 January, respectively. Arrows in (c) indicate the location of ground site measurements used for this study in northern Provo (NP), at the University of Utah (UU) and in Logan (L4). Borders of the sub-regions are shown in (c) for reference. Salt Lake City, the most populated area, is situated in the northeastern part of Salt Lake Valley.

ized by its intensive agricultural activities, including concentrated animal feeding operations (CAFOs). The regulatory environment of Cache Valley straddles the states of Utah and Idaho and comes under the jurisdiction of two different US EPA (Environmental Protection Agency) regions (8 and 10). Utah Valley (575000 inhabitants) borders Salt Lake Valley to the south via the Traverse Mountains and features Utah Lake, a large freshwater lake in the valley centre, and agricultural and industrial activities, including a major gas-fuelled power plant.

The objective of the UWFPS was to investigate wintertime air quality in the Salt Lake region, focusing on PCAP periods when formation of ammonium nitrate leads to high levels of $\mathrm{PM}_{2.5}$. NOAA's Twin Otter aircraft flights and ground site observations in each valley were used to probe the spatial distribution of trace gases and aerosols, with the aim of identifying their importance for $\mathrm{PM}_{2.5}$ and its formation mechanisms. A further objective of UWFPS was to investigate key emission sources of aerosol precursors and the role of agricultural, industrial, urban, mobile, home heating and natural emission sectors.

From 16 January to 12 February 2018 a total of 23 research flights were carried out with the Twin Otter aircraft covering a total of 58.3 flight hours. Flights were performed in a northern and southern flight pattern, where the northern pattern covered the northern metropolitan area, Cache Valley, Bear Valley, the Great Salt Lake, Tooele Valley and the northern part of Salt Lake Valley. The southern leg mainly encompassed Salt Lake Valley and Utah Valley. Figure 1 shows the region and county boundaries as well as a typical distribution of $\mathrm{NH}_{3}$ mixing ratios measured from the aircraft. Measurements were taken from ground level at the Salt Lake International Airport $(1288 \mathrm{~m}, 5225 \mathrm{ft})$ through $3800 \mathrm{~m}$ (12500 ft) a.s.l. when flying over inter-valley mountain ranges (Fig. S1b). The lowest cruising altitude was around $150 \mathrm{~m}(500 \mathrm{ft})$ above ground level. To probe vertical profiles near the surface, missed approaches were performed at seven different air fields throughout the region (Fig. S1b).

\subsection{Airborne ammonia measurements}

A continuous-wave quantum cascade tunable infrared laser differential absorption spectrometer (QC-TILDAS) (Ellis et al., 2010) was employed on the Twin Otter aircraft for measurements of $\mathrm{NH}_{3}$ (see Fig. 2) and operated on 21 of the 23 research flights $(53.6 \mathrm{~h})$. The single-laser instrument (QCmini, Aerodyne Research Inc., MA, USA) uses a multi-pass absorption cell ( $0.5 \mathrm{~L}, 76 \mathrm{~m}$ effective path length), which is purged with sample air to measure $\mathrm{NH}_{3}$. Due to its fast time response and high precision, the instrument is suited for aircraft measurements (Hacker et al., 2016; Pollack et al., 2019). The analyzer's precision can be $30 \mathrm{pptv}$ at a $1 \mathrm{~s}$ sampling rate under ideal ground-based operating conditions, which is comparable to chemical ionization mass spectrometry (Nowak et al., 2012) and significantly more precise than fast-time-response cavity ring-down spectrometers ( $>200 \mathrm{pptv}$ ). Prior to installation on the Twin Otter, the weight of the instrument could be reduced from its original value of 100 to $80 \mathrm{~kg}$ by using a smaller vacuum pump 
(SH-110, Varian Inc., MA, USA) for generating the sample flow rate and a modified inlet design. The $4 \mathrm{~L} \mathrm{~min}^{-1}$ flow rate through the sample cell was set by the critical orifice of a PFA (perfluoroalkoxy alkane; Teflon) virtual impactor, which acted as a particulate matter filter to avoid interferences from thermally dissociated ammonium aerosol and also to protect the cell mirrors. That thermal dissociation of ammonium aerosol was negligible is shown by measurement periods where $\mathrm{NH}_{3}$ was within the instrument's detection limit despite high levels ( $>20 \mathrm{ppbv}$ ) of measured particulate ammonium. As adsorption and desorption processes within the inlet system are major challenges for $\mathrm{NH}_{3}$ measurements, the time response of the system was optimized by introducing an additional bypass flow rate of $16 \mathrm{~L} \mathrm{~min}^{-1}$ to purge the inlet line (PFA, $3 / 8^{\prime \prime}$ outer diameter). The winglet that housed the inlet tubing was mounted directly above the QC-TILDAS allowing an inlet length of only $0.5 \mathrm{~m}$. To further minimize adsorption and desorption effects of $\mathrm{NH}_{3}$ and humidity to the tubing wall, the winglet was heated to $40^{\circ} \mathrm{C}$. The instrument time response can be best described by a double exponential function (Ellis et al., 2010; Whitehead et al., 2008), in which the fast time constant associated with the exchange of air volume $\left(\tau_{1}\right)$ was $0.7 \mathrm{~s}$ and the slow time constant associated with the wall effects $\left(\tau_{2}\right)$ was $27 \mathrm{~s}$ during a pre-flight test. The so-called $D$ value, which reflects the proportion of the decay governed by the slow time constant, was $21 \%$. These numbers compare very well with the time response of the same instrument using a $15.4 \mathrm{~L} \mathrm{~min}^{-1}$ sample flow rate without a bypass during another study designed for eddy covariance flux measurements (Moravek et al., 2019).

Variations in pressure, temperature and instrument vibrations may significantly impact the instrument performance by influencing the absorption spectrum fringe pattern. Optical interferences (fringes) are periodic structures in the absorption spectrum that influence precision and drift of the sensor if the fringes are of a wavelength comparable to the absorption linewidth. Changes in the fringe pattern, which can be induced by variations of pressure or temperature, may result in a drift of the $\mathrm{NH}_{3}$ mixing ratio over time. To account for changing ambient pressures with flight altitude, a pressure controller (PC3P, Alicat Scientific Inc., AZ, USA) was installed downstream of the absorption cell, which was able to keep the cell pressure at a constant value between 48.7 and $51.3 \mathrm{mbar}$. In-flight background measurements were performed manually approximately every 5 to $15 \mathrm{~min}$ to account for potential instrument drifts using zero air from ultra-zero air cylinders.

The precision of the instrument during the campaign was significantly degraded from its usual performance due to difficulties with the laser source. As a result, $\mathrm{NH}_{3}$ absorption was detected at $965.3 \mathrm{~cm}^{-1}$ instead of using the stronger absorption line at $967.3 \mathrm{~cm}^{-1}$. A measurement precision at a $1 \mathrm{~Hz}$ sample frequency of $150 \mathrm{pptv}(1 \sigma)$ could be achieved, which is similar to the background noise ( $200 \mathrm{pptv}$ ) of a QCTILDAS that was operated by Hacker et al. (2016) on a dif-

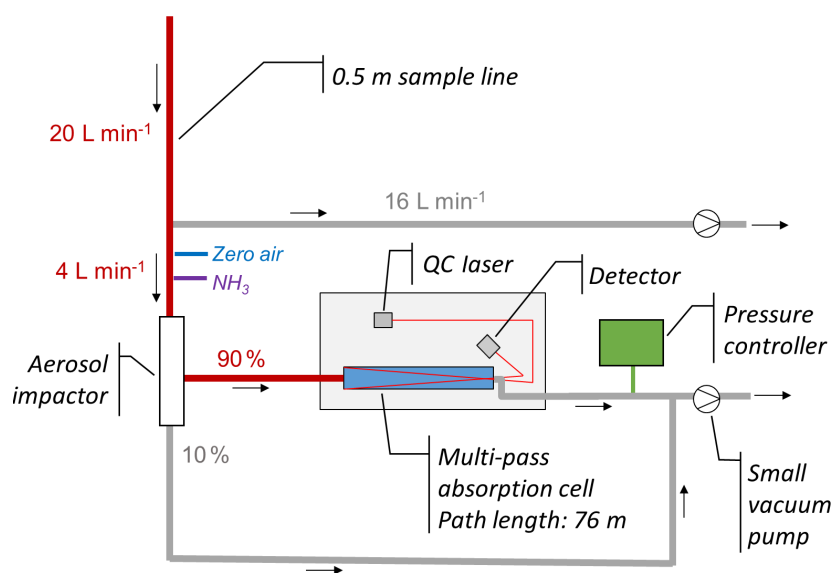

Figure 2. Setup of the QC-TILDAS on the Twin Otter aircraft for $\mathrm{NH}_{3}$ measurements at $1 \mathrm{~Hz}$ sample frequency. The commercially available QC-TILDAS was modified using a smaller vacuum pump, a pressure controller and a custom-made PFA aerosol impactor. To achieve an optimal time response, the used inlet line was only $0.5 \mathrm{~m}$, and a bypass system was used to generate a higher flow rate through the inlet line. The distances from the bypass to the aerosol impactor and from the aerosol impactor to the instrument's sample intake were also kept as short as possible $(<10 \mathrm{~cm})$. See text for further details on the setup.

ferent aircraft. Accordingly, the limit of detection $(3 \sigma)$ was $450 \mathrm{pptv}$ at $1 \mathrm{~Hz}$ and $90 \mathrm{pptv}$ for a $30 \mathrm{~s}$ averaging interval. Due to the effect of increased gravitational forces and vibrations on the optical alignment, data during take-off, landings, and spiralling ascents and descents were not used in this study. The filtering of the $\mathrm{NH}_{3}$ measurements was performed manually by identifying these periods through the altitude profile and then visually inspecting individual absorption spectra for the quality of the signal-to-noise ratio of the absorption peak. After the quality control, $38.7 \mathrm{~h}(72 \%)$ of $\mathrm{NH}_{3}$ data were used for the analysis. Ascents and descents of the missed approaches typically passed the quality test. An example of two missed approaches at the Logan airport is shown in Fig. S2. Next to the evidence of horizontal heterogeneity at the ground in one case (Fig. S2a), the other case (Fig. S2b) shows that the $\mathrm{NH}_{3}$ mixing ratios during descents and ascents are very similar if the same air mass is sampled. The fact that $\mathrm{NH}_{3}$ mixing ratios during ascents are not increased after sampling $\mathrm{NH}_{3}$-rich air at the ground illustrates the sufficient time response of the measurement system.

\subsection{Airborne measurements of other trace gases and aerosols}

The Twin Otter aircraft was equipped with an aerosol mass spectrometer (AMS, Aerodyne Research Inc., MA, USA) to measure the chemical composition of the nonrefractory aerosol particles in the $70-800 \mathrm{~nm}$ range (NRPM1) (Drewnick et al., 2005; Jayne et al., 2000) . The op- 
eration of the AMS during UWFPS was described in detail in Franchin et al. (2018). In brief, ambient aerosol particles are focused in an aerodynamic lens, evaporated, ionized with electron-impact ionization and detected by a mass spectrometer. The AMS measured mass loadings of particulate nitrate $\left(p \mathrm{NO}_{3}\right)$, ammonium $\left(p \mathrm{NH}_{4}\right)$, organic species, sulfate $\left(p \mathrm{SO}_{4}\right)$, chloride $(\mathrm{pCl})$ and total aerosol mass, with detection limits of $0.04,0.09,0.33,0.03,0.07$ and $0.38 \mu \mathrm{g} \mathrm{m}^{-3}$, respectively. The uncertainty on the total AMS mass concentrations was estimated to be $20 \%$ (Bahreini et al., 2008). Aerosol mass with the AMS was well-correlated with aerosol volume measured with an Ultra-High Sensitivity Aerosol Spectrometer (UHSAS, Droplet Measurement Technologies, CO, USA) on the same sampling line as the AMS.

Nitrogen oxides $\left(\mathrm{NO}_{x}=\mathrm{NO}+\mathrm{NO}_{2}\right)$, total reactive nitrogen $\left(\mathrm{NO}_{y}\right)$ and ozone $\left(\mathrm{O}_{3}\right)$ were measured at $1 \mathrm{~Hz}$ using the NOAA nitrogen oxides cavity ring-down instrument (NOx$\mathrm{CaRD})$. The instrument measures $\mathrm{NO}_{2}$ directly by optical absorption at $405 \mathrm{~nm}$, while $\mathrm{NO}$ and $\mathrm{O}_{3}$ are measured in two separate channels after quantitative conversion to $\mathrm{NO}_{2}$ by a reaction with excess $\mathrm{O}_{3}$ or NO, respectively (Fuchs et al., 2009; Washenfelder et al., 2011). A fourth channel measures $\mathrm{NO}_{y}$ by conversion to $\mathrm{NO}$ and $\mathrm{NO}_{2}$ in a heated quartz inlet $\left(650^{\circ} \mathrm{C}\right)$ and subsequent conversion of $\mathrm{NO}$ to $\mathrm{NO}_{2}$ in excess $\mathrm{O}_{3}$ (Wild et al., 2014). Accuracies for $\mathrm{NO}_{x}, \mathrm{NO}_{2}$ and $\mathrm{O}_{3}$ were $5 \%$ and $12 \%$ for $\mathrm{NO}_{y}$, based on previous comparisons of the $\mathrm{NO}_{y}$ measurement to a standard $\mathrm{NO}_{y}$ instrument (Wild et al., 2014).

A commercial probe (Avantech) measured meteorological parameters (ambient temperature, pressure, relative humidity with respect to liquid water, wind speed and wind direction), the global positioning satellite (GPS) location including altitude above sea level and aircraft parameters (heading, pitch and roll). Wind data were compromised for some flights, making only partial coverage (65\%-95\%) available for eight flights and resulting in no wind data for six of the 23 flights. The aircraft GPS altitude above sea level was converted into altitude above ground level using USGS data (USGS, 2017).

\subsection{Ground site observations}

During UWFPS, a series of ground measurements were conducted to measure the evolution of trace gases, aerosols and meteorology during the pollution episodes in the study region. Data used in this study were taken from the University of Utah ground site (UU) in Salt Lake Valley (40.7663, -111.8477), the Logan ground site (L4) in Cache Valley (41.7589, -111.8151) and the northern Provo ground site (NP) in Utah Valley $(40.2528,-111.6627)$ (Fig. 1c). The Logan ground site is referred to as L4 as it is located approximately $3 \mathrm{~km}$ northeast of the actual downtown federal reference site (named L4).

The UU site is located on the top floor of the William Browning Building on the University of Utah campus, which is situated on the northeast side of the Salt Lake Valley and approximately $150 \mathrm{~m}$ above the valley floor. A sampling inlet was located on top of a $7 \mathrm{~m}$ observation tower, at a height of $40 \mathrm{~m}$ a.g.l. Online measurements of ambient air $\mathrm{PM}_{2.5}$ composition and gas phase precursors were performed using the University of Toronto's modified Ambient Ion Monitoring System (AIM 9000D, URG Corp., NC, USA) coupled with two ion chromatographs (Dionex ICS-2000, Thermo Fisher Scientific Inc., ON, Canada). The system measures water soluble gases $\left(\mathrm{NH}_{3}, \mathrm{SO}_{2}, \mathrm{HNO}_{3}\right)$ and particles $\left(p \mathrm{NH}_{4}, p \mathrm{SO}_{4}\right.$, $\left.p \mathrm{NO}_{3}\right)$ at an hourly resolution using parallel wet denuders (Markovic et al., 2012). Continuous $\mathrm{PM}_{2.5}$ mass concentrations were determined using the 8500 Filter Dynamics Measurement System (FDMS) coupled with a 1400ab Continuous Ambient Particulate TEOM (tapered element oscillating microbalance) Monitor (Thermo Fisher Scientific Inc., MA, USA). Instrumental background measurements were conducted by introducing an overflow of zero air into the AIM-IC inlet and sampled for a $24 \mathrm{~h}$ period. Based on background experiments, the $3 \sigma$ detection limits were determined to be $0.15 \mathrm{ppb}$ for $\mathrm{NH}_{3}$ and $0.3 \mu \mathrm{g} \mathrm{m}^{-3}$ (at standard temperature and pressure) for $p \mathrm{NH}_{4}$.

The L4 ground site was a temporary sampling station during UWFPS, located on the Utah State University campus in Logan, employing an environmentally controlled shelter with the inlet extending through the shelter roof to a height of $5 \mathrm{~m}$ a.g.l. Ambient mixing ratios of $\mathrm{NH}_{3}$ were obtained with a Picarro G2508 cavity ring-down spectroscopy instrument (Picarro Inc., CA, USA). The analyzer collected on a nominal $5 \mathrm{~s}$ sampling frequency, which is averaged up to 1 min sample periods. At $1 \mathrm{~min}$ averaging times the G2508 has a precision of $<3 \mathrm{ppbv}$ and measured detection limit $(3 \sigma)$ of $2.3 \mathrm{ppb}$. A Teledyne API T640 measured continuous mass concentrations of $\mathrm{PM}_{2.5}, \mathrm{PM}_{10}$ and $\mathrm{PM}_{10-2.5}$ at the $\mathrm{L} 4$ ground site.

At the NP site, mass concentration of $\mathrm{PM}_{2.5}$ was monitored by the Utah Division of Air Quality using a 1405DF TEOM Continuous Dichotomous Ambient Air Monitor (Thermo Fisher Scientific Inc., MA, USA). No $\mathrm{NH}_{3}$ measurements were available from this site.

\subsection{The UDAQ emission inventory}

To better understand the formation of ammonium nitrate in the study region, it is important to identify and quantify the major sources of $\mathrm{NH}_{3}$. In northern Utah, $\mathrm{NH}_{3}$ from livestock, fertilizer and on-road vehicle emissions are the most dominant $\mathrm{NH}_{3}$ sources, according to the emission inventory provided by the Utah Division of Air Quality (UDAQ). The Utah emissions inventory is created by UDAQ and ultimately informs the emissions estimates found in the US Environmental Protection Agency's National Emission Inventory (NEI). Yearly totals of county-wide emission data for criteria and other significant air pollutants $\left(\mathrm{NO}_{x}\right.$, VOC, direct $\mathrm{PM}_{10}$, direct $\mathrm{PM}_{2.5}, \mathrm{NH}_{3}, \mathrm{SO}_{2}, \mathrm{CO}$ and others) were processed in the SMOKE v3.6.5 (Sparse Matrix Operator Kernel Emissions) 
Table 1. $\mathrm{NH}_{3}$ emission estimates and measurements by region. Data include (1) total $\mathrm{NH}_{3}$ emission estimates and their sector-based proportion from the UDAQ emission inventory; (2) $\mathrm{NH}_{3}$ emission estimates for Cache Valley from the USU emission inventory; (3) measured and modelled $\mathrm{NH}_{x}$ mixing ratios (mean and standard deviation); (4) the ratio between measured and modelled $\mathrm{NH}_{x}$ mixing ratios (scaling factor). The regions are Bear Valley (BV; Box Elder County), Cache Valley (CV; Cache County and Franklin County), Great Salt Lake (GSL; Box Elder County, Weber County, Davis County, Salt Lake County and Tooele County), the northern metropolitan area (NM; Davis County and Weber County), Tooele County (TC) and Utah Valley (UV; Utah County).

\begin{tabular}{|c|c|c|c|c|c|c|c|c|c|}
\hline \multirow[b]{3}{*}{ Region } & \multicolumn{6}{|c|}{$\mathrm{NH}_{3}$ emission estimates } & \multicolumn{2}{|c|}{ Mixing ratios } & \multirow{3}{*}{$\begin{array}{r}\text { Scaling factors } \\
\mathrm{dNH}_{x \_ \text {meas }} \\
\mathrm{dNH}_{x \_ \text {model }} \\
\text { mean (median) }\end{array}$} \\
\hline & \multicolumn{5}{|c|}{ UDAQ } & USU & Twin Otter & Model & \\
\hline & $\begin{array}{r}\text { Total } \\
\left(\mathrm{kg} \mathrm{d}^{-1}\right)\end{array}$ & $\begin{array}{l}\text { Area } \\
(\%)\end{array}$ & $\begin{array}{r}\text { Mobile } \\
(\%)\end{array}$ & $\begin{array}{r}\text { Non-road } \\
(\%)\end{array}$ & $\begin{array}{r}\text { Point } \\
(\%)\end{array}$ & $\begin{array}{r}\text { Total } \\
\left(\mathrm{kg} \mathrm{d}^{-1}\right)\end{array}$ & $\begin{array}{r}\mathrm{dNH}_{x \_ \text {meas }} \\
(\mathrm{ppbv})\end{array}$ & $\begin{array}{r}\mathrm{dNH}_{x \_ \text {model }} \\
(\mathrm{ppbv})\end{array}$ & \\
\hline $\mathrm{BV}$ & 3514 & 97.2 & 2. & 0.0 & 0.3 & - & $4.09( \pm 4.09)$ & $0.82( \pm 0.95)$ & $5.0(6.3)$ \\
\hline $\mathrm{CV}$ & 4757 & 96.7 & 2.9 & 0.0 & 0.4 & 12435 & $7.50( \pm 9.65)$ & $1.70( \pm 1.47)$ & $4.4(2.7)$ \\
\hline GSL & - & - & - & - & - & - & $4.47( \pm 4.68)$ & $0.63( \pm 0.96)$ & $7.1(12.2)$ \\
\hline NM & 2218 & 58.8 & 21.5 & 0.3 & 19.4 & - & $10.04( \pm 8.77)$ & $2.00( \pm 2.06)$ & $5.0(4.7)$ \\
\hline SLV & 2016 & 34.4 & 49.3 & 0.6 & 15.7 & - & $3.61( \pm 4.01)$ & $1.87( \pm 2.30)$ & 1.9 (1.9) \\
\hline $\mathrm{TC}$ & 1486 & 92.7 & 6.2 & 0.0 & 1.1 & - & $2.78( \pm 3.21)$ & $0.33( \pm 0.49)$ & $8.4(10.7)$ \\
\hline UV & 6058 & 85.5 & 7.2 & 0.1 & 7.2 & - & $3.78( \pm 4.15)$ & $2.33( \pm 1.94)$ & $1.6(1.2)$ \\
\hline
\end{tabular}

emissions processing software to obtain higher temporally and spatially resolved emission estimates (Baek and Seppanen, 2018). UDAQ uses two modelling domains: (1) a larger $4 \mathrm{~km}$ resolution outer domain covering the state of Utah and portions of surrounding states and (2) a smaller $1.33 \mathrm{~km}$ inner domain covering the Wasatch Range and Cache Valley, representing the majority of the $\mathrm{PM}_{2.5}$ non-attainment area in northern Utah. Temporal allocation in SMOKE consists of defining emission distributions through the use of monthly, weekly and hourly profiles, which were applied to the yearly emission totals.

Inventory data were compiled for four distinct emission sectors: area, non-road, mobile and point sources. Area sources are typically of larger spatial extent than point sources, but they may also include multiple non-mobile point sources of the same category if the individual emission of each point source is unknown. Total estimated daily $\mathrm{NH}_{3}$ emissions from each sector are given in Table 1 for the regions in the study area. $\mathrm{NH}_{3}$ emissions in all regions are dominated by areas sources with the exception of Salt Lake Valley, where $\mathrm{NH}_{3}$ from mobile sources are thought to be dominant.

Area sources include $\mathrm{NH}_{3}$ emissions from fertilizer applications, livestock and residential wood combustion. Emissions from livestock are the largest portion of area sources in Utah County (71\%) and Cache County $(81 \%)$, while they are only minor in Salt Lake County (11\%). The NEI-based $\mathrm{NH}_{3}$ emissions from livestock are based on county-level animal populations, which are multiplied by daily resolved emission factors that are representative for each animal type and management practice. These location-specific emission factors are produced by the Farm Emission Model (FEM) for each day of the modelled year by taking meteorological as well as animal type and practice input data (McQuilling and
Adams, 2015). For the compilation of $\mathrm{NH}_{3}$ emissions from fertilizer applications, a bidirectional exchange model uses meteorological and application-based input data. The Environmental Policy Integrated Climate (EPIC) modelling system provides information regarding fertilizer timing, composition, application method and amount. A bidirectional version of the Community Multiscale Air Quality (CMAQ) model is then used to calculate county-level emission factors which are multiplied by county-level total fertilizer estimates to obtain $\mathrm{NH}_{3}$ emissions. For both livestock and fertilizer $\mathrm{NH}_{3}$ emissions, annual NEI emission totals were multiplied in SMOKE by monthly, weekly and hourly profiles.

Non-road emissions include emissions from nonstationary sources, except commuter automobiles. For example, non-road sources would include construction equipment, snowmobiles, boats, trains and aircraft. Similar to mobile emissions, non-road emissions are mainly projected using the MOVES (MOtor Vehicle Emission Simulator) 2014a model. However, the emissions from trains, aircraft and airport ground support equipment are estimated from specific EPA-provided tools.

Mobile emissions were calculated and projected using the MOVES 2014a model, which were then input into SMOKE as precomputed mobile inventory numbers. Mobile emissions are informed by vehicle population data and vehiclespecific emission rate information. Also, various metropolitan planning organizations supply UDAQ with the traffic activity data that goes into MOVES 2014a.

Point sources include large emitters such as oil refineries, power plants and big mining operations. Since the vertical release height of point stack emissions impacts air quality, the 2-D SMOKE gridded emissions output was input into the air-quality model (CAMx 6.30), which calculates vertical plume rise from those point source stack parameters using 42 
layers matching Weather Research and Forecasting (WRF) inputs.

\subsection{Modelling of ammonia concentrations using STILT}

To account for the atmospheric transport of $\mathrm{NH}_{3}$ from emission sources to the receptors of the $\mathrm{NH}_{3}$ measurement observations made during UWFPS, we used the Stochastic Time-Inverted Lagrangian Transport model (Lin et al., 2003). STILT simulated the upstream influence by modelling the evolution of ensembles of 200 simulation particles, each representing an air parcel $24 \mathrm{~h}$ back in time. Particle ensembles are considered to be influenced by surface fluxes when they spend time in the vertically well-mixed surface layer (defined as $50 \%$ of the boundary layer height). STILT compiles a "footprint", a flux sensitivity matrix, using the flux sensitivity from each of the 200 trajectories. The flux sensitivity represents the contribution of a grid cell area to the $\mathrm{NH}_{3}$ mixing ratio per surface flux unit. To obtain footprints for the aircraft measurements, STILT was run for every 2 min of the Twin Otter flight path for all 23 research flights. STILT was driven with gridded meteorological information available from NOAA's High Resolution Rapid Refresh (HRRR) model (HRRR, 2017), which covers the entire continental US. HRRR is based upon the widely used Weather Research and Forecasting mesoscale model (Skamarock and Klemp, 2008) and resolves the atmosphere at $3 \mathrm{~km}$ grid spacing, assimilating radar observations.

Model $\mathrm{NH}_{3}$ enhancements (in pptv) were estimated by multiplying the flux sensitivity data (in $\operatorname{ppmv}\left(\mu \mathrm{mol} \mathrm{m}{ }^{-2}\right.$ $\left.\mathrm{s}^{-1}\right)^{-1}$ ) with the $\mathrm{NH}_{3}$ emissions from the UDAQ emission inventory (in $\mu \mathrm{mol} \mathrm{m}^{-2} \mathrm{~s}^{-1}$ ) for each grid cell. As STILT was run $24 \mathrm{~h}$ back in time, the modelled $\mathrm{NH}_{3}$ enhancements represent the $\mathrm{NH}_{3}$ mixing ratio contribution from surface emissions within the last $24 \mathrm{~h}$. Before multiplying, the $\mathrm{NH}_{3}$ emissions were resampled to the match the spatial grid of the flux sensitivity data $\left(0.01^{\circ} \times 0.01^{\circ}\right)$. Modelled $\mathrm{NH}_{3}$ enhancements were then obtained by summing the $\mathrm{NH}_{3}$ contributions from each grid cell. To account for the large spatial extent of the $24 \mathrm{~h}$ trajectories from the Twin Otter position, the $1.33 \mathrm{~km}$ inventory data were inset into the larger $4 \mathrm{~km}$ inventory in order to have the maximal spatial extent but also make use of the refined $\mathrm{NH}_{3}$ emissions of the $1.33 \mathrm{~km}$ emission inventory.

To account for the formation of particle ammonium from emitted $\mathrm{NH}_{3}$, the modelled $\mathrm{NH}_{3}$ estimates were compared to measured total $\mathrm{NH}_{x}$ (which is $\mathrm{NH}_{3}+p \mathrm{NH}_{4}$ ). Conversion to particulate ammonium is the dominant reactive sink for gas phase $\mathrm{NH}_{3}$ as the oxidation of $\mathrm{NH}_{3}$ by $\mathrm{OH}$ is significantly slower. Thus using $\mathrm{NH}_{x}$ as a passive tracer is reasonable, however, the approach does not account for potential dry and wet deposition of $\mathrm{NH}_{3}$. As a result of this simplification, modelled $\mathrm{NH}_{x}$ enhancements could be overestimated. Modelled $\mathrm{NH}_{x}$ enhancements only account for $\mathrm{NH}_{3}$ emitted within the past $24 \mathrm{~h}$ in the spatial domain of the produced $\mathrm{NH}_{3}$ contributions map and do not include $\mathrm{NH}_{x}$ ad- vected from outside that spatial domain or $\mathrm{NH}_{3}$ which was present in the air shed before the $24 \mathrm{~h}$ period. Therefore, an estimate of background $\mathrm{NH}_{x}$ mixing ratios was subtracted from measured $\mathrm{NH}_{x}$ mixing ratios before comparing them to the modelled enhancements. Background mixing ratios were determined separately for each region listed in Sect. 2.1 (see Fig. 1a) using the measured $\mathrm{NH}_{x}$ mixing ratios data from each individual flight in the respective region. To account for varying vertical mixing between flights, the data were split into vertical layers of $50 \mathrm{~m}$ depth covering the entire altitude range of the Twin Otter. The background mixing values specific for each layer, region and flight were then determined by the 1st percentile of $\mathrm{NH}_{x}$ data from the Twin Otter. As shown in Fig. S15, for areas with significant $\mathrm{NH}_{3}$ surface emissions, the 1st percentile was well above the instrument's detection limit. If the background mixing ratio was underestimated, this would lead to unrealistically high estimates of the $\mathrm{NH}_{x}$ enhancements from the measurements. Also, we found that the results did not change significantly by using a slightly lower $(0.1 \mathrm{st})$ or higher (2nd) percentile.

In the remainder of the text, we refer to modelled $\mathrm{NH}_{3}$ and measured $\mathrm{NH}_{x}$ enhancements as modelled and measured $\mathrm{dNH}_{x}$, respectively.

\section{Results and discussion}

\subsection{Meteorological conditions and PCAP episodes}

Weather conditions in the Great Salt Lake region in January and February 2017 included episodes of winter storms and above-average precipitation. As storm tracks promote vertical mixing, PCAP periods were less frequent during UWFPS than typically observed. Within the period of the Twin Otter measurements, two major PCAP periods were identified: PCAP\#1 from 13 to 20 January 2017 and PCAP\#2 from 27 January to 4 February 2017. A third and less intense PCAP period occurred at the end of the campaign on 13 February and lasted until 18 February 2017. The strong atmospheric stability during those PCAP periods lead to the build-up of high $\mathrm{PM}_{2.5}$ levels for Salt Lake Valley, Cache Valley and Utah Valley, as shown in Fig. 3. Due to the lack of snow cover and the relatively weak subsidence inversion, the inversion height during PCAP\#1 was atypically high, reaching from about 400 up to $800 \mathrm{~m}$ a.g.l., before a strong storm initiated the top-down erosion of the PCAP on 19 January. During PCAP\#1, ground-level $\mathrm{PM}_{2.5}$ reached up to $90 \mu \mathrm{g} \mathrm{m}^{-3}$ in Cache Valley (L4) and up to $50 \mu \mathrm{g} \mathrm{m}^{-3}$ in Salt Lake Valley (UU), while the PCAP was only weakly developed in Utah Valley (NP) with $\mathrm{PM}_{2.5}$ levels below $20 \mu \mathrm{g} \mathrm{m}^{-3}$ ( $1 \mathrm{~h}$ averages). In contrast, PCAP\#2 was a stronger, classic PCAP period, which was promoted by several inches of fresh snow and cold air left by a storm that was followed by a large high-pressure period. This resulted in $\mathrm{PM}_{2.5}$ values building up in all three major valleys over the course of the 

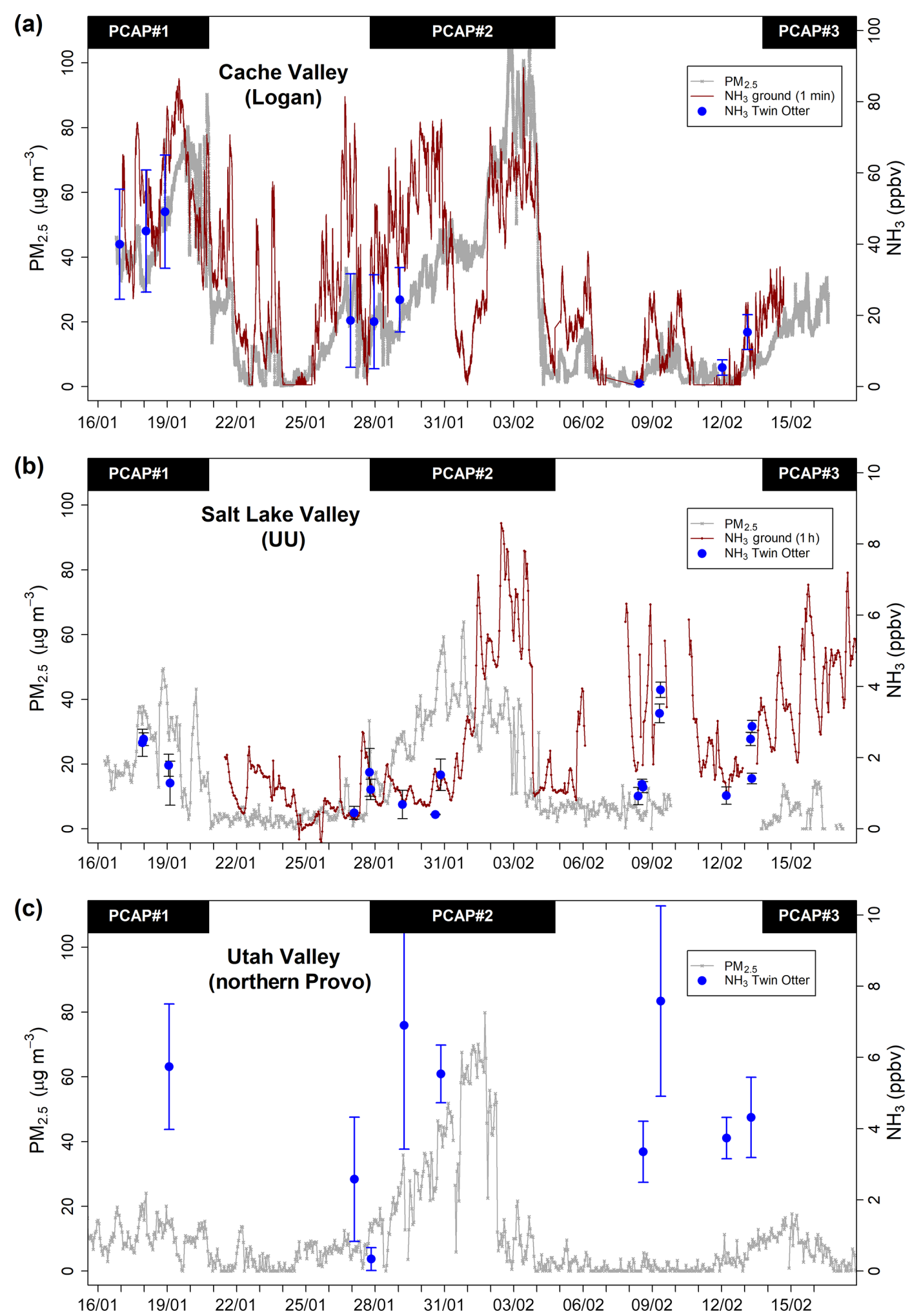

Figure 3. Time series of fine particulate matter $\left(\mathrm{PM}_{2.5}\right)$ and $\mathrm{NH}_{3}$ mixing ratios during PCAP periods over the course of the measurement campaign from 16 January to 13 February 2017. Shown are measurements from the ground sites (a) in Logan (L4), (b) at the University of Utah (UU) and (c) in northern Provo (NP). Blue dots represent mean $\mathrm{NH}_{3}$ mixing ratios measured from the Twin Otter during missed approaches (at Logan airport and northern Provo airport) or when flying over the UU measurement site. The time frames of the three PCAP periods during the campaign are marked as black bars. 
PCAP and reaching $104 \mu \mathrm{g} \mathrm{m}^{-3}$ at the $\mathrm{L} 4,64 \mu \mathrm{g} \mathrm{m}^{-3}$ at the $\mathrm{UU}$ and $80 \mu \mathrm{g} \mathrm{m}^{-3}$ at the NP sites ( $1 \mathrm{~h}$ averages). As evident in the $\mathrm{PM}_{2.5}$ data, the PCAP started eroding in Utah Valley first, then in Salt Lake Valley second, whereas it persisted a few days longer in Cache Valley, which is also attributed to the deeper snow cover in Cache Valley during January and February 2017. Compared to PCAP\#2, PCAP\#3 was moderate with only the onset captured by the aircraft flights.

\subsection{Observed $\mathrm{NH}_{3}$ mixing ratios}

\subsubsection{Evolution of ammonia mixing ratios near the surface}

Ammonia mixing ratios measured at the $\mathrm{L} 4$ and $\mathrm{UU}$ ground sites (Fig. 3) correlate with increasing $\mathrm{PM}_{2.5}$ levels during PCAP periods, especially at the $\mathrm{L} 4$ site (Fig. 3a), where $\mathrm{NH}_{3}$ reached up to $100 \mathrm{ppbv}$ during PCAP\#1 and PCAP\#2. The correlation between $\mathrm{PM}_{2.5}$ and $\mathrm{NH}_{3}$ indicates the presence of local $\mathrm{NH}_{3}$ sources and illustrates the strong influence of atmospheric stability on pollutant concentrations during winter. $\mathrm{NH}_{3}$ mixing ratios show a stronger diurnal variation than $\mathrm{PM}_{2.5}$. Accumulation of directly emitted $\mathrm{NH}_{3}$ in the nocturnal boundary layer leads to transient enhancements of $\mathrm{NH}_{3}$ mixing ratios, which is for example visible in the short-term $(<12 \mathrm{~h}) \mathrm{NH}_{3}$ peaks observed during nighttime at the $\mathrm{L} 4$ site (e.g. nights of 8-9 and 9-10 February). Although $\mathrm{PM}_{2.5}$ formation occurs through both daytime and nighttime processes, the nighttime process is typically fast in the residual layer and suppressed in the surface layer (McDuffie et al., 2019; Womack et al., 2019). At the UU site, ambient $\mathrm{NH}_{3}$ measurements were significantly lower than in Cache Valley, typically below $10 \mathrm{ppbv}$ (Fig. 3b). Measurements are not available for PCAP\#1; however, the build-up of $\mathrm{NH}_{3}$ mixing ratios in Salt Lake Valley is evident in the second half of PCAP\#2. Increasing $\mathrm{PM}_{2.5}$ levels mark the first half of PCAP\#2, while $\mathrm{NH}_{3}$ mixing ratios were still low between 1 and 3 ppbv. During that period, $\mathrm{NH}_{3}$ mainly partitioned into $p \mathrm{NH}_{4}$, as it was observed by the simultaneous increase of $p \mathrm{NH}_{4}$ with $\mathrm{PM}_{2.5}$ (data not shown).

Near-surface mixing ratios were sampled from the Twin Otter aircraft during missed approaches at regional airfields (Figs. S1 and S2). Figure 3a shows $\mathrm{NH}_{3}$ mixing ratios at Logan airport, located about $3 \mathrm{~km}$ northwest of the $\mathrm{L} 4$ ground site. $\mathrm{NH}_{3}$ mixing ratios from the Twin Otter follow the trend of the ground measurements with (1) high mixing ratios between 45 and 55 ppbv during PCAP\#1, (2) medium mixing ratio levels between 20 and $25 \mathrm{ppbv}$ during the first half of PCAP\#2, and (3) lower mixing ratios below 20 ppbv towards the end of the measurement campaign. The direct comparison of ground site and Twin Otter measurements was performed by averaging the Twin Otter mixing ratios within a distance of $1 \mathrm{~km}$ of the airport runway and obtaining the mean ground site mixing ratios for the same time interval. As shown in Fig. S4b, mean values from the Twin Otter are roughly a factor of 2 lower than measurements from the L4 ground site. This can be explained by the dilution of $\mathrm{NH}_{3}$ mixing ratios from higher altitudes, as the averaging window for the Twin Otter values partially includes $\mathrm{NH}_{3}$ measurements from the ascents and descents of the missed approaches. For that reason, maximum values better represent the ground level mixing ratios, which is supported by a closer correspondence with the data from the L4 site. Furthermore, Moore (2007) and Hammond et al. (2017) showed that mean $\mathrm{NH}_{3}$ concentrations can vary spatially across the Cache Valley by as much as an order of magnitude, depending on the strength of adjacent sources and duration of a PCAP event. For Salt Lake Valley, $\mathrm{NH}_{3}$ measured at the UU site compares generally well with the airborne $\mathrm{NH}_{3}$ obtained when the Twin Otter was overflying the ground site (Fig. 3b). The direct comparison of both measurements (Fig. S4a) shows that airborne measurements are on average lower, attributed to the higher altitude of the measurement and the vertical gradient of $\mathrm{NH}_{3}$ away from the surface.

The $\mathrm{NH}_{3}$ mixing ratios at the $\mathrm{L} 4$ ground site were about 1 order of magnitude larger than at the UU ground site. This compares well with the AMoN measurements, where during the measurement period in January and February the average $\mathrm{NH}_{3}$ concentration was $2 \mu \mathrm{g} \mathrm{m}^{-3}$ in Salt Lake City (UT97) and $16 \mu \mathrm{g} \mathrm{m}^{-3}$ in Cache Valley (UT01). The 2017 AMoN measurements are representative for the average $\mathrm{NH}_{3}$ concentrations measured between 2012 and 2018 in those months $\left(3 \mu \mathrm{g} \mathrm{m}^{-3}\right.$ in Salt Lake City and $16 \mu \mathrm{g} \mathrm{m}^{-3}$ in Cache Valley). This shows that despite the less frequent PCAP periods observed compared to other years, the $\mathrm{NH}_{3}$ concentrations were still comparatively high during the measurement campaign.

\subsubsection{Prevailing $\mathrm{NH}_{3}$ mixing ratios in different regions from aircraft observations}

The frequency distributions of $\mathrm{NH}_{3}$ mixing ratios measured in Salt Lake Valley, in Cache Valley, in Utah Valley and over the Great Salt Lake are shown in Fig. $4 a$ and $b$ for both PCAP and non-PCAP conditions. Mixing ratios were filtered to only include those from the lowest steady flight level (data between 100 and $500 \mathrm{~m}$ a.g.l) for a better comparison between regions. The histograms reveal that during both PCAP and non-PCAP conditions $\mathrm{NH}_{3}$ mixing were mostly below 3 ppbv above the Great Salt Lake and mostly below 5 ppbv in Salt Lake Valley, with only a few measurements outside of those limits. The majority of $\mathrm{NH}_{3}$ measurements in both Cache Valley and Utah Valley were also below 5 ppbv; however, higher mixing ratios up to $20 \mathrm{ppbv}$ in Cache Valley and $10 \mathrm{ppbv}$ in Utah Valley were also frequently observed. While the distributions for all regions are similar under PCAP and non-PCAP conditions, during PCAP conditions higher extreme values up to around $70 \mathrm{ppbv}$ in both Cache Valley and Utah Valley were observed at the lowest steady flight level, indicating the presence of local emission sources. Higher lev- 

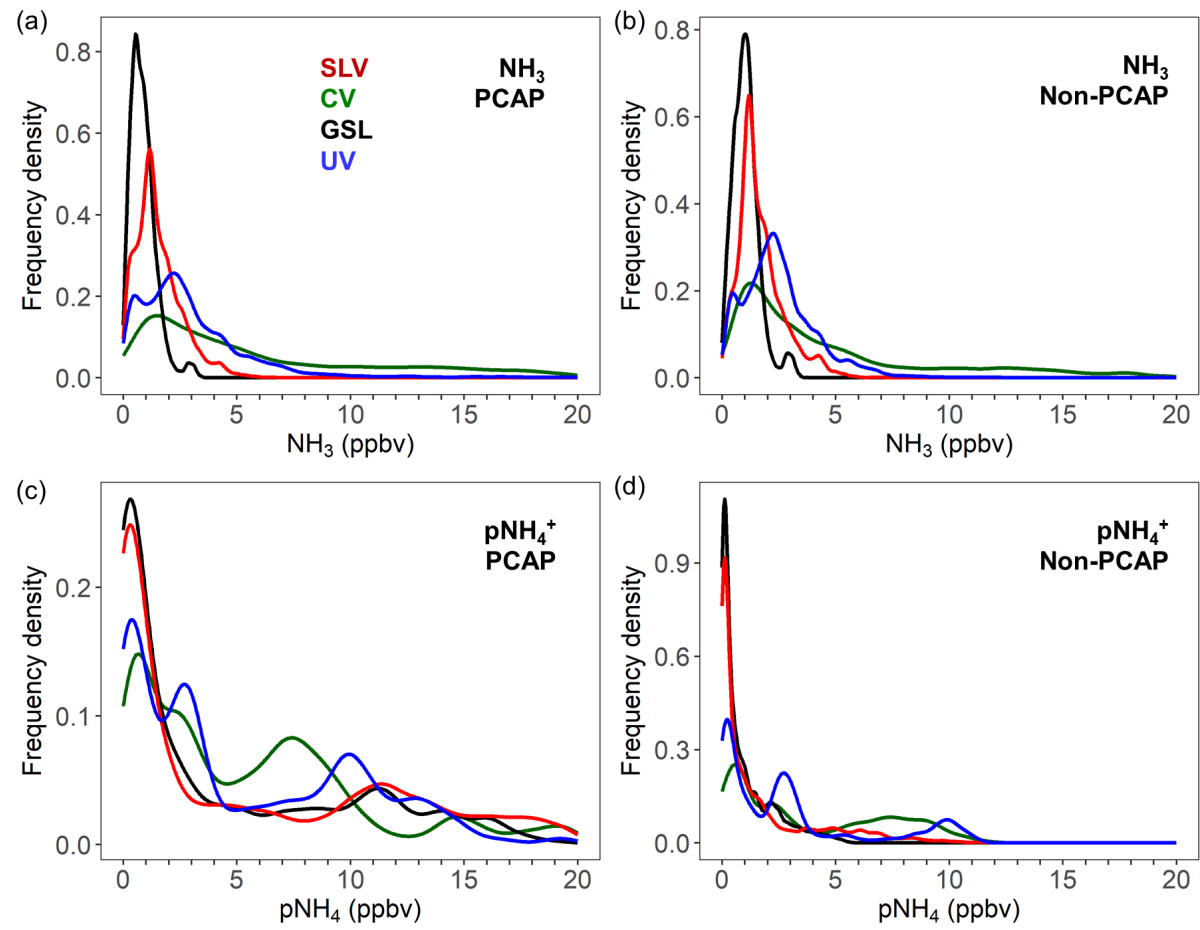

Figure 4. Frequency distribution of $\mathrm{NH}_{3}(\mathbf{a}, \mathbf{b})$ and $\mathrm{pNH}_{4}(\mathbf{c}, \mathbf{d})$ mixing ratios measured from the Twin Otter in Salt Lake Valley (SLV), Cache Valley (CV), Utah Valley (UV) and above the Great Salt Lake (GSL). The distributions are based on mixing ratios from all research flights, segregated into PCAP $(\mathbf{a}, \mathbf{c})$ and non-PCAP $(\mathbf{b}, \mathbf{d})$ conditions.

els up to nearly $90 \mathrm{ppbv}$ were only measured during missed approaches at the Logan airport in Cache Valley, marking it as a distinct high $\mathrm{NH}_{3}$ region. In contrast to $\mathrm{NH}_{3}$, the frequency distributions of $p \mathrm{NH}_{4}$ show a clear difference between PCAP and non-PCAP periods (Fig. 4c, d), with significantly higher $p \mathrm{NH}_{4}$ values during PCAP conditions. This can be explained by the increased partitioning of $\mathrm{NH}_{3}$ into the particle phase and build-up of ammonium nitrate over the course of the PCAP periods (Fig. 3).

\subsection{Evaluation of $\mathrm{NH}_{3}$ emission sources}

\subsubsection{Comparison of modelled and measured enhancements}

To investigate $\mathrm{NH}_{3}$ emissions sources in the different regions, we compare $\mathrm{dNH}_{x}$ measured on the Twin Otter with $\mathrm{dNH}_{x}$ derived from the footprint model (see Sect. 2.5 and 2.6). Figure 5 shows an example of a STILT flux sensitivity footprint and how it is overlaid with the UDAQ emission inventory to obtain $\mathrm{dNH}_{x}$ estimates for the locations of the Twin Otter.

The mean measured and modelled $\mathrm{dNH}_{x}$ for all regions in the study area are given in Table 1, including a scaling factor which is the ratio of $\mathrm{dNH}_{x_{-}}$meas $/ \mathrm{dNH}_{x_{-}}$model. Figure 6 shows the frequency distribution for modelled and measured $\mathrm{dNH}_{x}$ for Salt Lake Valley, Cache Valley and Utah Valley for
non-PCAP (panels a-c) and PCAP (panels $\mathrm{d}-\mathrm{f}$ ) conditions. The distributions show that the model underestimates $\mathrm{dNH}_{x}$ in all three valleys, compared to the measurements from the Twin Otter. During non-PCAP conditions, the underestimation is most prominent in Cache Valley. During PCAP conditions the underestimation is in general more pronounced than during non-PCAP conditions. As during PCAP periods $\mathrm{NH}_{x}$ mainly persists as $p \mathrm{NH}_{4}$ (see Sect. 3.2.2), this leads to the high measured $\mathrm{dNH}_{x}$ over the course of the PCAP period in Salt Lake Valley and Utah Valley. Due to high local $\mathrm{NH}_{3}$ emissions, in Cache Valley $\mathrm{NH}_{3}$ and $p \mathrm{NH}_{4}$ are of similar magnitude, which is why the difference between PCAP and non-PCAP periods is slightly less pronounced (see also linear scale distributions in Fig. S9).

Lower modelled $\mathrm{dNH}_{x}$ values may suggest an underestimation of $\mathrm{NH}_{3}$ emissions in the UDAQ inventory. Table 1 lists the mean measured and modelled $\mathrm{dNH}_{x}$ mixing ratios for the different regions in the study area, which were used to derive a mean scaling factor between measured and modelled values. The mean scaling factor for Cache Valley, Salt Lake Valley and Utah Valley are 4.4, 1.9 and 1.6, respectively, which reflects that modelled $\mathrm{dNH}_{x}$ are underestimated in all three valleys. Due to the non-Gaussian distribution of both measured and modelled $\mathrm{dNH}_{x}$ values, the median scaling factors vary but still show the same trend for the underestimation of modelled $\mathrm{dNH}_{x}$, with the highest underestima- 

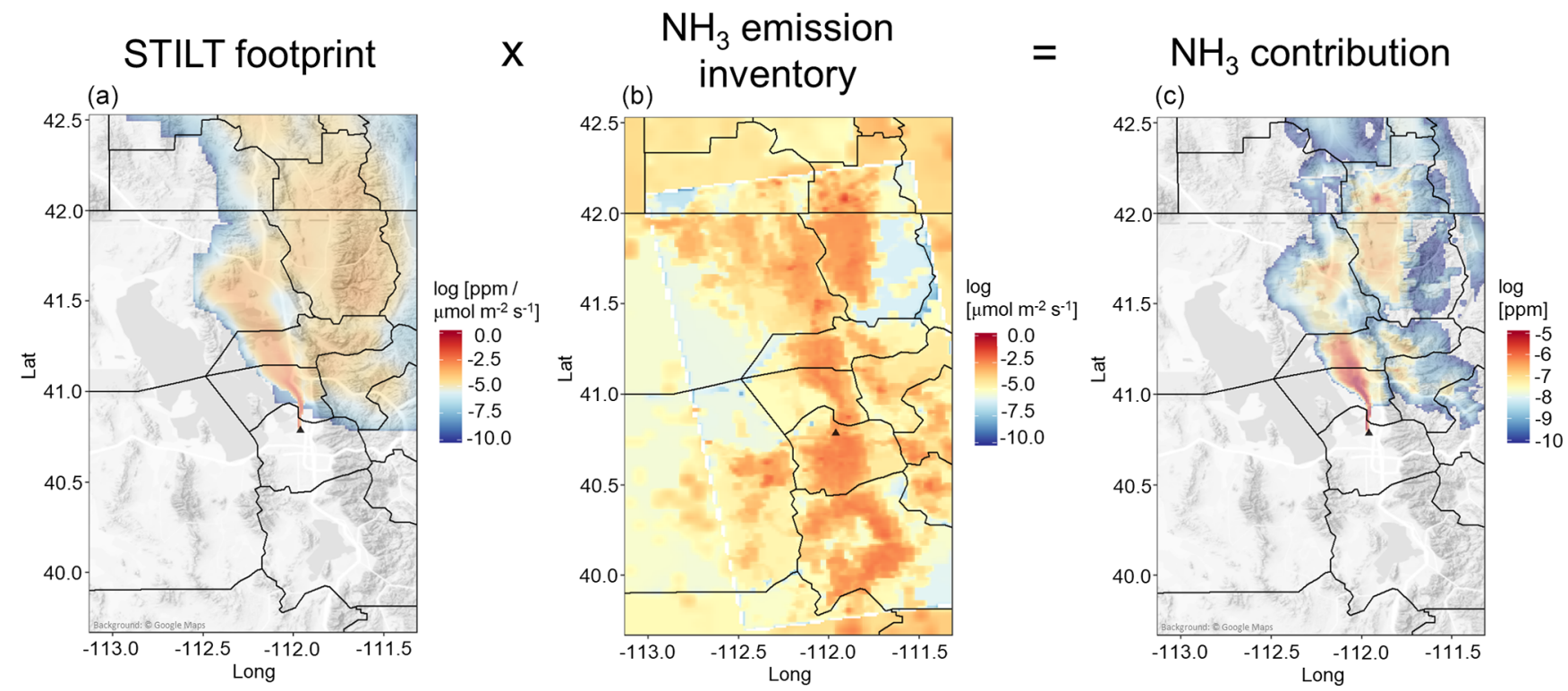

Figure 5. Approach used to determine $\mathrm{NH}_{3}$ enhancements by overlaying the emission sensitivity map (in ppmv $\left(\mu \mathrm{mol} \mathrm{m} \mathrm{m}^{-2} \mathrm{~s}^{-1}\right)^{-1}$, a) with the $\mathrm{NH}_{3}$ emissions from the UDAQ emission inventory (in $\mu \mathrm{mol} \mathrm{m} \mathrm{m}^{-2} \mathrm{~s}^{-1}, \mathbf{b}$ ). The emission sensitivities were derived with STILT for every 2 min of the Twin Otter flight path for all research flights. $\mathrm{NH}_{3}$ enhancement for the Twin Otter location were obtained by summing all $\mathrm{NH}_{3}$ contributions within the spatial domain of the $\mathrm{NH}_{3}$ contribution map (c). The $\mathrm{NH}_{3}$ emission inventory map (b) is a composite of the $1.33 \times 1.33 \mathrm{~km}^{2}$ resolution emission inventory in the centre, imbedded into the $4 \times 4 \mathrm{~km}^{2}$ emission inventory.

tion in Cache Valley (2.7), followed by Salt Lake Valley (1.9) and Utah Valley (1.2).

To further discuss the discrepancies between measured and modelled $\mathrm{dNH}_{x}$ values, it is important to address the uncertainties of both measured and modelled $\mathrm{dNH}_{x}$, which we discuss in the following section.

\subsubsection{Uncertainties in measured and modelled mixing ratio enhancements}

Calculations of the trajectories and footprints with the STILT model rely on the accurate representation of meteorological conditions and parameterizations such as the definition of the height of the surface mixed layer, which couples the ground surface emissions to the calculated trajectories. While we do not go in detail on the STILT parameterization and the derived weather model (HRRR), the examination of $\mathrm{NO}_{y}$ enhancements above background mixing ratios $\left(\mathrm{dNO}_{y}\right)$, which were also measured from the Twin Otter, confirms that the overall representation of the meteorology is reasonable. Figures S12 and S13 show the frequency distributions for measured and modelled $\mathrm{dNO}_{y}$. The scaling factors $\left(\mathrm{dNO}_{y_{-}}\right.$meas $/ \mathrm{dNO}_{y_{-}}$model $)$for Cache Valley, Salt Lake Valley and Utah Valley were 1.3, 1.0 and 0.9, respectively, which shows agreement of measured and modelled $\mathrm{dNO}_{y}$ for all of the three valleys. This indicates that on average both meteorological conditions and $\mathrm{NO}_{y}$ emissions are represented adequately in the model approach we used. This interpretation relies on the assumption that both the $\mathrm{NO}_{x}$ emission inventory and $\mathrm{NO}_{y}$ measurements are accurate. As particulate nitrate $\left(p \mathrm{NO}_{3}\right)$ is only quantitatively sampled by the NOxCaRD if it enters the inlet (not designed specifically for aerosol sampling), $\mathrm{NO}_{y}$ measurements may be biased as being too low. By comparing the $\mathrm{NO}_{y}$ to the AMS $p \mathrm{NO}_{3}$ (after subtracting $\mathrm{NO}_{x}$ and other relevant $\mathrm{NO}_{y}$ species), we found that inlet sampling was effectively quantitative to within the uncertainty in the AMS (20\%) and $\mathrm{NO}_{y}$ $(12 \%)$ measurements. Furthermore, since the $\mathrm{NO}_{x} / \mathrm{NO}_{y}$ ratio was always fairly large $(0.53 \pm 0.34)$, a significant amount of $\mathrm{NO}_{y}$ was present as $\mathrm{NO}_{x}$. While the agreement in the frequency distributions is good, the direct comparison of modelled and measured $\mathrm{dNH}_{x}$ reveals a relatively poor point-topoint correlation (Fig. S8). A similarly poor correlation was found for $\mathrm{dNO}_{y}$ (Fig. S12) and also for measured and modelled $\mathrm{dNH}_{x}, \mathrm{dNO}_{y}$ and $\mathrm{dCO}_{2}$ at the UU ground site (data not shown), which shows that there is no clear bias in either the STILT footprints from the Twin Otter or in the $\mathrm{NH}_{3}$ inventory.

Due to the finite extent of the combined UDAQ emission inventory map (Sect. 2.5), fractions of the STILT footprints may be outside of the emissions inventory domain. For both Salt Lake Valley and Utah Valley, more than $50 \%$ of the $24 \mathrm{~h}$ footprints lie completely within the inventory domain during PCAP conditions, while only a small number have a contribution from outside of the domain of $50 \%$ or more. As Cache Valley is located close to the northern border of the UDAQ emission inventory map (Fig. 1), a larger fraction of footprints exceeded the inventory domain, with $18 \%$ of 
(a)

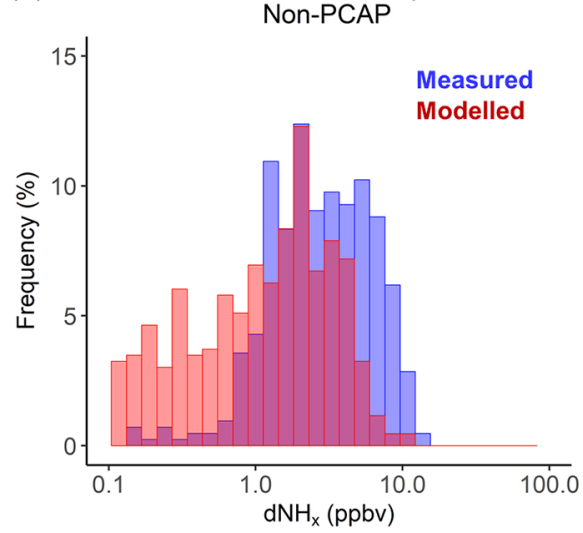

(d)

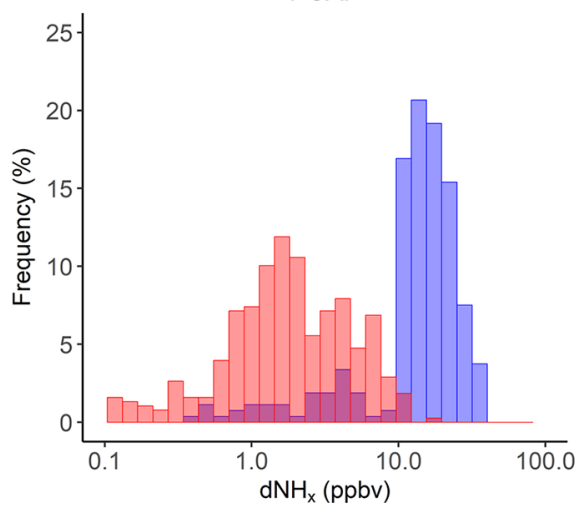

(b)
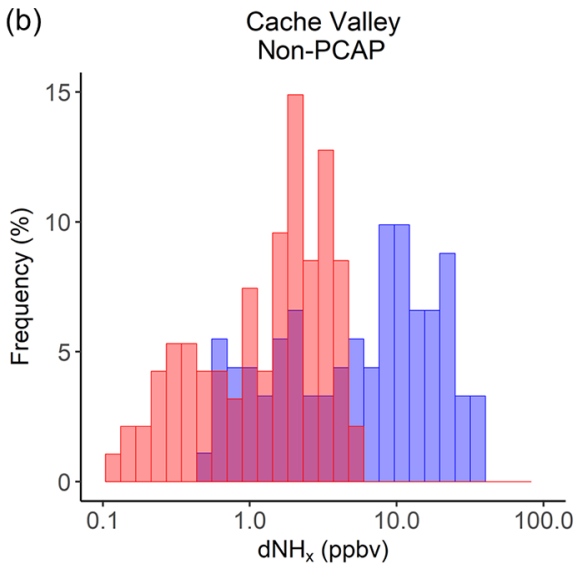

(e)

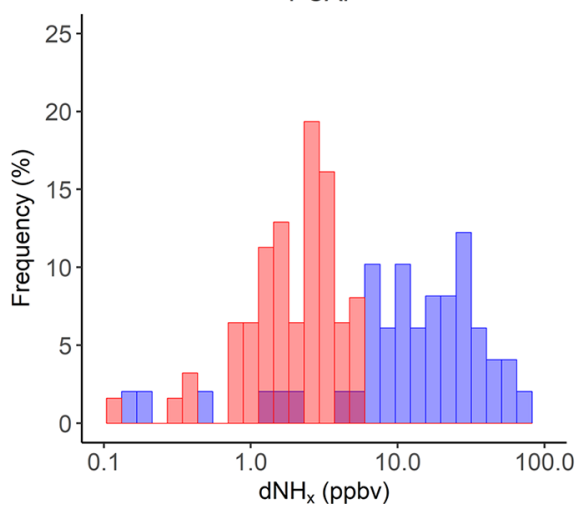

(c)

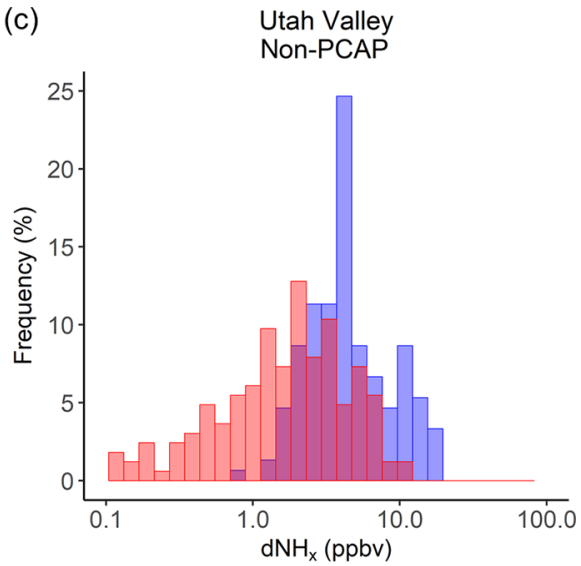

(f)
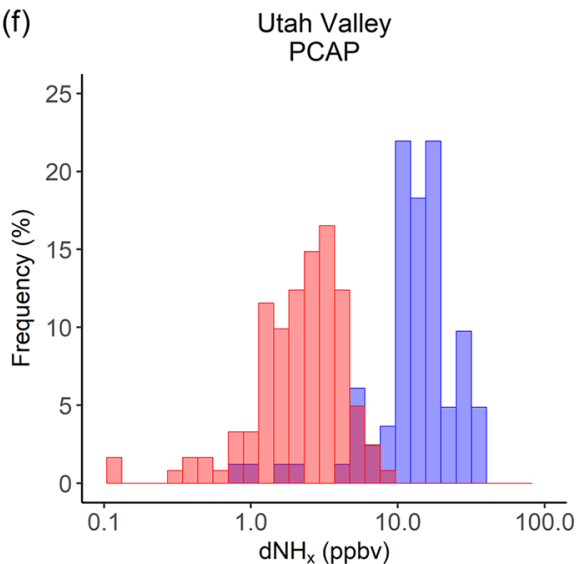

Figure 6. Frequency distribution of measured (blue) and modelled (red) $\mathrm{NH}_{x}$ enhancements $\left(\mathrm{dNH}_{x}\right)$ for Salt Lake Valley, Cache Valley and Utah Valley on logarithmic scales for $(\mathbf{a}-\mathbf{c})$ non-PCAP and (d-f) PCAP conditions.

footprints completely within the inventory domain and $63 \%$ of footprints at least $50 \%$ within the domain during PCAP conditions. However, this effect cannot explain the large underestimation of modelled $\mathrm{dNH}_{x}$ in Cache Valley due to the following reasons: (1) the analysis of the STILT trajectories (Fig. S16) showed that air masses for a majority of the extreme measured $\mathrm{dNH}_{x}$ values in Cache Valley originated in low $\mathrm{NH}_{x}$ environments (at high altitudes or areas with low $\mathrm{NH}_{3}$ emissions) and (2) high mixing ratios were only observed in Cache Valley (see also Fig. 4), providing evidence that measured $\mathrm{dNH}_{x}$ was dominated by local $\mathrm{NH}_{3}$ sources. Advection of high amounts of $\mathrm{NH}_{3}$ from the north would have also strongly affected other regions such as the Great Salt Lake, which the measurements do not show.

Uncertainties of measured $\mathrm{dNH}_{x}$ values arise from uncertainties in the measurements from the Twin Otter and uncertainties in the background determination (Sect. 2.2 and 2.3). The precision of $\mathrm{NH}_{3}$ mixing ratios was 0.03 ppbv for a $1 \mathrm{~min}$ averaging period, which was used for the comparison. The uncertainty of $p \mathrm{NH}_{4}$ is given as $20 \%$. Given the uncertainty in the measurements and an uncertainty of the background determination method, the distinction between small measured and modelled $\mathrm{dNH}_{x}$ differences is difficult. As a re- sult, although the scaling factors in Table 1 suggest that $\mathrm{NH}_{3}$ emissions in Salt Lake Valley are underestimated by $50 \%$, it is possible that part or all of the model-measurement mismatch could be due to method uncertainties rather than an underrepresentation of $\mathrm{NH}_{3}$ emission in the UDAQ inventory. In contrast, the large differences between measured and modelled $\mathrm{dNH}_{x}$ in Cache Valley cannot be attributed to measurement errors, and therefore it is more likely attributed to an underestimation of $\mathrm{NH}_{3}$ emission in the UDAQ inventory in Cache Valley.

\subsubsection{Modification of modelled $\mathrm{dNH}_{x}$ using scaling factors}

To investigate the effect of a possible underestimation of $\mathrm{NH}_{3}$ emissions in the UDAQ inventory on the presented $\mathrm{dNH}_{x}$ distributions, we scaled the modelled $\mathrm{dNH}_{x}$ by the scaling factors given in Table 1. For Cache Valley, if we assume that all the underestimation in modelled $\mathrm{dNH}_{x}$ is due to an underestimation in livestock emissions (see Sect. 3.3.4), we can adjust the scaling factors in Table 1 to be solely applied to area source emissions. Accordingly, the area source scaling factor for Cache Valley is 4.55 . If we apply this fac- 
(a)

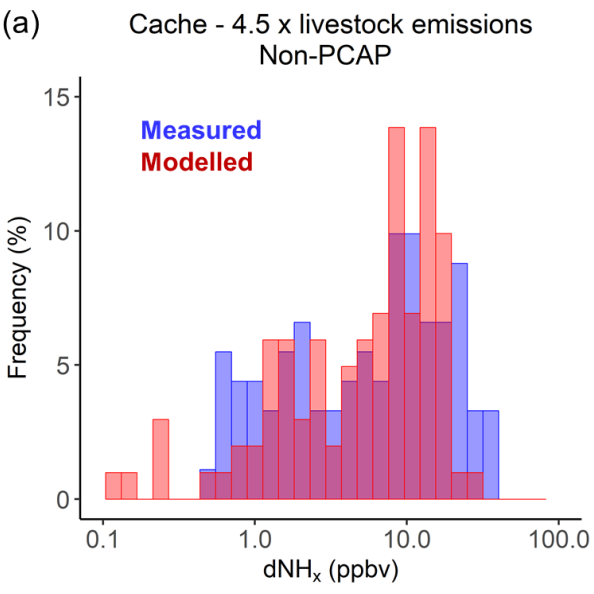

(c)
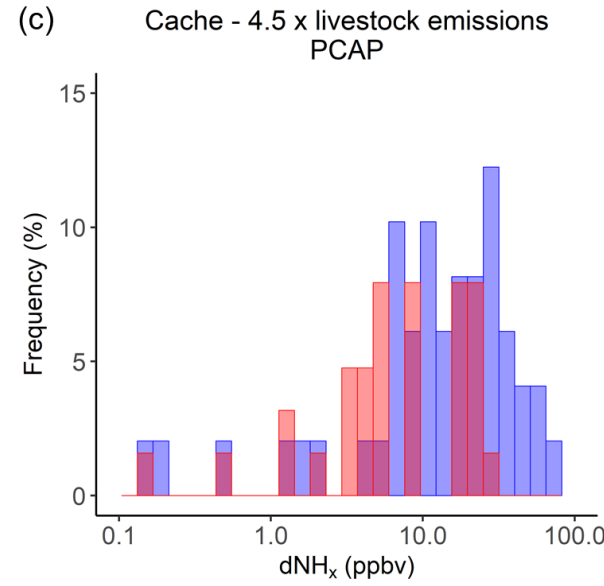

(b) Cache - USU inventory Non-PCAP

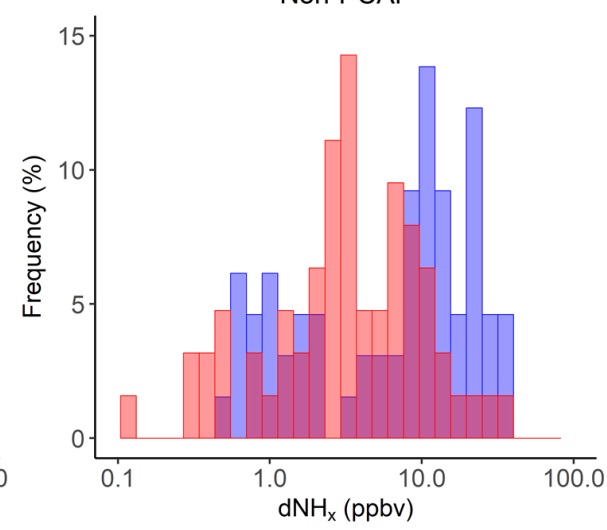

(d)

Cache - USU inventory

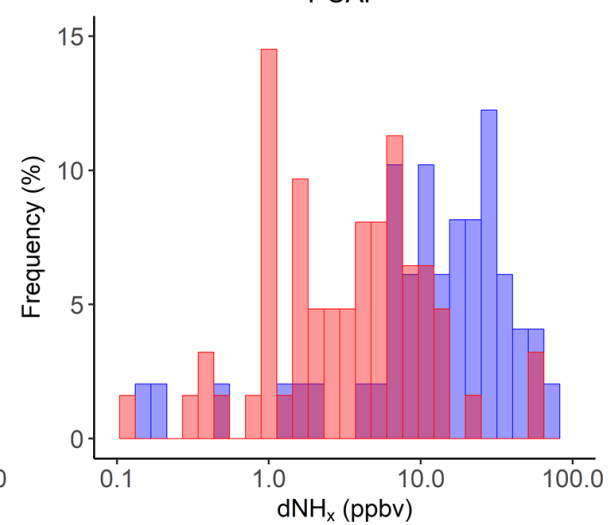

Figure 7. Frequency distribution of measured (blue) and modelled (red) $\mathrm{NH}_{x}$ enhancements $\left(\mathrm{dNH}_{x}\right.$ ) for Cache Valley, using enhanced livestock emissions by a factor of 4.5 and the USU emission inventory for (a, b) non-PCAP and (c, d) PCAP conditions.

tor to the modelled $\mathrm{dNH}_{x}$ in Cache Valley, the range of measured and modelled $\mathrm{dNH}_{x}$ agrees well for non-PCAP conditions (Fig. 7a). As the same factor is applied to all modelled $\mathrm{dNH}_{x}$, the shape of the distribution does not change significantly, and a much larger scaling factor would be necessary to reproduce measured $\mathrm{dNH}_{x}$ values up to $88 \mathrm{ppbv}$ for the PCAP conditions (Fig. 7c). A Mann-Whitney-Wilcoxon test was used to evaluate the agreement between the modelled and measured $\mathrm{dNH}_{x}$ distribution before and after applying the scaling factor (Table S2). The increase of $p$ values above the 0.05 significance level indicates that the distributions of modelled and measured $\mathrm{dNH}_{x}$ show similarity after applying the scaling factor. Assuming a systematic underestimation of livestock emissions, we also applied the same scaling factor to area source emissions in Salt Lake Valley and Utah Valley. As illustrated in Fig. S10, for Salt Lake Valley the modified modelled $\mathrm{dNH}_{x}$ values are not significantly larger, which is due to the fact that emissions from area sources play a less important role in Salt Lake Valley than in Cache Valley or Utah Valley (Table 1). Since the largest emissions source in Salt Lake Valley is the mobile sector, modelled $\mathrm{dNH}_{x}$ values for all three valleys were additionally modified by a scaling factor, which was retrieved from the ratio of modelled and measured $\mathrm{dNH}_{x}$ values in Salt Lake Valley (Fig. S11). Applying the factor (of 3 ) to the mobile emissions of modelled $\mathrm{dNH}_{x}$ yields a better agreement for Salt Lake Valley during non-PCAP conditions; however, the large frequency of measured $\mathrm{dNH}_{x}$ above 10 ppbv during PCAP conditions cannot be explained. This suggests that especially during PCAP conditions either (1) background $\mathrm{NH}_{x}$ mixing ratios used to calculate measured $\mathrm{dNH}_{x}$ are higher than accounted for or (2) the surface influence in STILT is underestimated in Salt Lake Valley.

The underestimation of $\mathrm{NH}_{3}$ emissions in inventories compared to inferences from measurements is in agreement with findings from several other studies that examine industrial, agricultural and vehicle emissions. For example, Sun et al. (2017) found from vehicle-based measurements of $\mathrm{NH}_{3} / \mathrm{CO}_{2}$ ratios that $\mathrm{NH}_{3}$ vehicle emissions are more than twice those reported in the 2011 NEI. Van Damme et al. (2018) state that the EDGAR (Emission Database for Global Atmospheric Research) emission inventory mostly agrees with satellite-derived $\mathrm{NH}_{3}$ emission fluxes within a factor of 3 for larger regions but underestimates the $\mathrm{NH}_{3}$ 
emissions from many point sources by at least 1 order of magnitude, while most of those emission hotspots were associated with either high-density animal farming or industrial fertilizer production. Similar conclusions are made from aircraft observations by Nowak et al. (2012), who suggest that $\mathrm{NH}_{3}$ emissions from dairy facilities in the South Coast Air Basin were significantly underestimated (by a factor of 10100) by the 2005 NEI. However, it has to be noted that significant differences between spatial and seasonal variations of $\mathrm{NH}_{3}$ emissions between inventories exist (Zhang et al., 2018), which complicates a direct comparison of the scaling factors presented in literature.

\subsubsection{Ammonia emissions in Cache Valley: uncertainties in livestock emissions}

The results presented above suggest that $\mathrm{NH}_{3}$ emissions may be underestimated in the UDAQ emission inventory, with the highest underestimation in Cache Valley. According to the inventory, $96.7 \%$ of total $\mathrm{NH}_{3}$ emissions in Cache Valley are attributed to emissions from area sources. Cache Valley area sources are dominated by emissions from cattle waste $(56.2 \%)$ and poultry operations $(20.6 \%)$. Emissions from fertilizer application only account for $6.8 \%$, and emissions from swine production only account for $3.1 \%$ of the total area sources. As cattle waste is by far the largest $\mathrm{NH}_{3}$ source in Cache Valley, it therefore seems most likely that an underrepresentation of cattle waste emissions are at least partially responsible for the gap between measured and modelled $\mathrm{dNH}_{x}$.

In the UDAQ inventory, sources from livestock emissions are treated as area sources and distributed uniformly over the county or an area in the county. As a result, high $\mathrm{NH}_{3}$ emissions released by CAFOs are spread over a larger area instead of being treated as a point source. This may be another reason why the higher measured $\mathrm{dNH}_{x}$ values are not reproduced by the model. As the UDAQ inventory does not report the location of CAFOs, we modelled $\mathrm{dNH}_{x}$ using a $\mathrm{NH}_{3}$ emission inventory compiled by Utah State University (USU), which reports facility-based emissions from livestock in Cache Valley (see Sect. S4 for a description of the inventory). The USU inventory compiled emissions from dairy cattle, beef cattle, swine, poultry, automobiles, wastewater treatment facilities and industry for both Cache and Franklin Counties for the year 2006 (Table S1). In wintertime, the largest $\mathrm{NH}_{3}$ source of emissions in Cache Valley was dairy cattle (89.6\%), while $98.1 \%$ of total emissions were from the livestock sector. Figure S6 spatially locates the facility-based livestock, poultry and other area source $\mathrm{NH}_{3}$ emissions in Cache Valley and visually indicates estimated relative source strengths. To derive modelled $\mathrm{dNH}_{x}$ estimates, we replaced the UDAQ $\mathrm{NH}_{3}$ emissions in Cache Valley with these facility-based emissions from the USU inventory. These emissions were embedded into the UDAQ emission inventory map (Fig. S7) before overlaying them with the STILT footprints from the Twin
Otter. Compared to the original UDAQ inventory, the USU inventory produces higher modelled $\mathrm{dNH}_{x}$ values, which compare better to $\mathrm{dNH}_{x}$ measured from the Twin Otter. The USU emissions yield a mean modelled $\mathrm{dNH}_{x}$ value of 5.05( \pm 8.38$)$ ppbv, as shown in Table 1, whereas using the UDAQ inventory, this value was only $1.70( \pm 1.47)$ ppbv. Maximum modelled $\mathrm{dNH}_{x}$ values from each inventory are 61.7 and $5.7 \mathrm{ppbv}$, respectively. Mean $\mathrm{dNH}_{x}$ mixing ratios from the USU are a factor of 2.55 higher than from the UDAQ inventory, which agrees with the ratio between total emission rates from each inventory in Cache Valley given in Table $1\left(12435 \mathrm{~kg} \mathrm{~d}^{-1} / 4757 \mathrm{~kg} \mathrm{~d}^{-1}=2.61\right)$. In comparison to measured $\mathrm{dNH}_{x}$, the scaling factor (all sectors included) decreases from 4.4 to only 1.5 when using the USU inventory.

Possible reasons for the underestimation of $\mathrm{NH}_{3}$ emissions in the UDAQ inventory could be differences in the livestock numbers or differences in livestock emission factors used in the inventories. As described in Moore (2007), the USU inventory uses animal counts from 2007, derived from personal discussions with count extension agents, local producers and co-op organizations, with approximately 90000 dairy cattle in Cache Valley (40000 in Cache County; 50000 in Franklin County) and nearly 2000000 chickens. The USU inventory is based on a $\mathrm{NH}_{3}$ emission factor between 152.7 and $161.3 \mathrm{~g} \mathrm{~d}^{-1} \mathrm{AU}^{-1}$ (AUs; animal units), depending on the cattle age and waste disposal method. Dairy cattle emissions in the UDAQ are based on the county-wide estimates of the 2014v1 NEI inventory. As mentioned in Sect. 2.5, the FEM used in the NEI inventory produces location-specific emission factors for each day of the modelled year (McQuilling and Adams, 2015). In SMOKE, annual NEI emission totals are multiplied by monthly, weekly and hourly profiles to obtain temporally resolved emissions. The monthly profile redistributes the annual total NEI emissions over the year and is determined through inverse modelling, as described in Gilliland et al. (2006). $\mathrm{NH}_{x}$ observational data from the National Atmospheric Deposition Program (NADP) are used together with prior seasonal $\mathrm{NH}_{3}$ emission estimates in the CMAQ model to produce a region-specific monthly profile. The monthly profile used in the UDAQ inventory is presented in Fig. S5 showing a clear seasonal cycle of livestock emissions. Emissions peak in summer, with more than $18 \%$ of annual emissions in July, while emissions are lowest in wintertime. This seasonal profile is typically explained by increases in fertilizer application, a higher fraction of outdoor housing and higher temperatures in summer than in winter. However, a significant month-to-month variation is present. Especially in wintertime, when expected emissions are lower, the percentage variation between months is significant. This suggests uncertainties in wintertime livestock emissions, in particular as the monthly profile is based on the year 2005. Furthermore, as shown in Table S1, the USU inventory suggests nearly similar livestock emissions for both summer and winter. This is supported by higher surface $\mathrm{NH}_{3}$ concentrations 
on average observed in winter than summer in Cache Valley by the authors of the inventory in 2006 (Moore, 2007). It is beyond the scope of this study to evaluate the uncertainties of inventory livestock emissions in detail. A larger measurement dataset and also a more thorough consideration of other processes such as $\mathrm{NH}_{x}$ deposition are necessary.

\subsection{Inter-valley exchange of $\mathrm{NH}_{3}$ and impact on PM formation}

Exchange of air masses between valleys or basins in the study region can be a critical factor for air pollution formation. Especially in wintertime when air pollutants accumulate in the valley basins during PCAP periods, the transport of air pollutants or their precursors from adjacent valleys can increase local air pollution. If $\mathrm{NH}_{3}$ from agriculture in Cache Valley is transported to Salt Lake Valley, its equilibrium with $\mathrm{HNO}_{3}$ produced from oxidation of $\mathrm{NO}_{x}$ emitted by mobile and industrial sources may affect the limiting reagent and thus the control strategy for ammonium nitrate $\mathrm{PM}_{2.5}$ formation in Utah's most densely populated region (Franchin et al., 2018). Similarly, $\mathrm{NO}_{x}$ enriched air masses transported from Salt Lake Valley may lead to $\mathrm{PM}_{2.5}$ formation in Cache Valley. Utah Valley is connected with Salt Lake Valley via the Jordan Narrows, where an exchange of air masses between the two basins is frequently observed. For example, after a mix-out episode at the end of a PCAP period in Salt Lake Valley, Mitchell et al. (2018) observed the transport of $\mathrm{PM}_{2.5}$-enriched air from Utah Valley, where the PCAP was still persistent. Similarly, we observed from the Twin Otter the transport of $\mathrm{NH}_{3}$-rich air masses through the Jordan Narrows into Salt Lake Valley, induced by southerly winds during PCAP\#1 on 18 January 2017 (mixing ratios in Utah Valley and Salt Lake Valley for that day are shown in Fig. 1c).

To investigate how inter-valley exchange affects air pollution in the Great Salt Lake region, we examined the origin of air masses through the STILT footprint calculation. The $\mathrm{dNH}_{x}$ contribution from each county to the modelled total $\mathrm{dNH}_{x}$ was determined for the Twin Otter footprints by using emissions from the UDAQ inventory. In addition we determined the county contribution to $\mathrm{dNH}_{x}$ at the UU site, where hourly STILT emission enhancements were available for the period from 16 to 31 January 2017. Due to the lower elevation of the ground-based UU site compared to the Twin Otter aircraft, the extent of the footprints is typically smaller; however, footprints for UU provide more continuous temporal coverage over the investigated period.

Figure 8a shows the $\mathrm{dNH}_{x}$ contributions for Salt Lake Valley (UU site and Twin Otter), Cache Valley (Twin Otter) and Utah Valley (Twin Otter). Results for the other regions in the study area are presented in Fig. S17. The contributions were segregated by county (e.g. Salt Lake County instead of Salt Lake Valley) as political boundaries are more appropriate divisions for emission control and air pollution regulation. In Salt Lake Valley, the largest portion of $\mathrm{dNH}_{x}$ at the
UU site is attributed to emissions from Salt Lake County for both PCAP $(66.3 \%)$ and non-PCAP $(77.2 \%)$ conditions. As Twin Otter footprints extend further than those from surface observations, $\mathrm{NH}_{3}$ contributions from Salt Lake County are slightly smaller (47.6\% and $40.8 \%)$.

The second-largest contributions are from Davis County adjoining to the north of Salt Lake Valley (13.0\% and 24.2\% for Twin Otter). Contributions from Utah County are small at the UU site $(8.2 \%$ and $3.7 \%)$, but they are larger $(16.9 \%)$ for the Twin Otter-derived footprints during PCAP periods, as the aircraft also sampled the south section of Salt Lake Valley. This is consistent with frequently observed southerly winds during PCAP periods and shows the importance of inter-valley exchange during these conditions. Contributions from Cache County were only minor $(0.5 \%$ and $0.0 \%$ at UU site, $2.6 \%$ and $6.5 \%$ for Twin Otter over Salt Lake Valley) and negligible from Franklin County $(0.0 \%$ at the UU site, $0.1 \%$ and $1.7 \%$ for Twin Otter over SLV). This shows that the impact of the high agricultural emissions in Cache Valley on $\mathrm{PM}_{2.5}$ formation in Salt Lake Valley was not significant during the study period. As shown in Fig. S18, the transport of $\mathrm{NH}_{3}$ from Cache County and Franklin County into the medium densely populated northern metropolitan area (Weber County and Davis County) was also minor $(<2 \%)$ during PCAP periods. Segregating the contributions from each county by emission sector, we found that $55 \%$ are from area emissions and about $30 \%$ from mobile sources (Fig. S19). If we account for the observed underestimation of emission sources in the UDAQ inventory by increasing area source and mobile emissions by a factor 4.5 and 3 , respectively, (Fig. S20) and take the average values retrieved from the Twin Otter and the UU site, during the study period about $60 \%$ of $\mathrm{dNH}_{x}$ in Salt Lake Valley originated from area source emissions and $30 \%$ are from mobile source emissions in the region. Future analyses of relationships between $\mathrm{NH}_{3}$ and tracers for different emission sources, such as $\mathrm{CO}, \mathrm{CO}_{2}$, $\mathrm{CH}_{4}, \mathrm{NO}_{x}$ and VOCs, will be useful in refining the apportionment of $\mathrm{NH}_{3}$ emission sources from this campaign.

For Cache Valley, during PCAP conditions $64.2 \%$ of $\mathrm{dNH}_{x}$ contributions were from Cache Valley, while $21.1 \%$ were transported from Box Elder County, which is connected through a canyon in the west mountain range of Cache Valley. Due to excess $\mathrm{NH}_{3}$ in Cache Valley, ammonium nitrate formation is mostly nitrate limited (Franchin et al., 2018). Therefore, the advection of nitrate or $\mathrm{NO}_{x}$ may be a significant process for $\mathrm{PM}_{2.5}$ formation in Cache Valley. Figure $8 \mathrm{~b}$ shows the percentage of county contributions for $\mathrm{dNO}_{y}$ (for all regions see Fig. S18). As they are based on the same STILT footprints, percentages are similar to the $\mathrm{dNH}_{x}$ contributions, but they differ due to a different distribution of $\mathrm{NO}_{x}$ emission sources. During PCAP conditions, $19.5 \%$ of $\mathrm{dNO}_{y}$ in Cache Valley was emitted in Box Elder County, $16.8 \%$ in Davis County, $13.0 \%$ in Weber County and $11 \%$ in Salt Lake County. This suggests that a large fraction of $\mathrm{NO}_{x}$ po- 

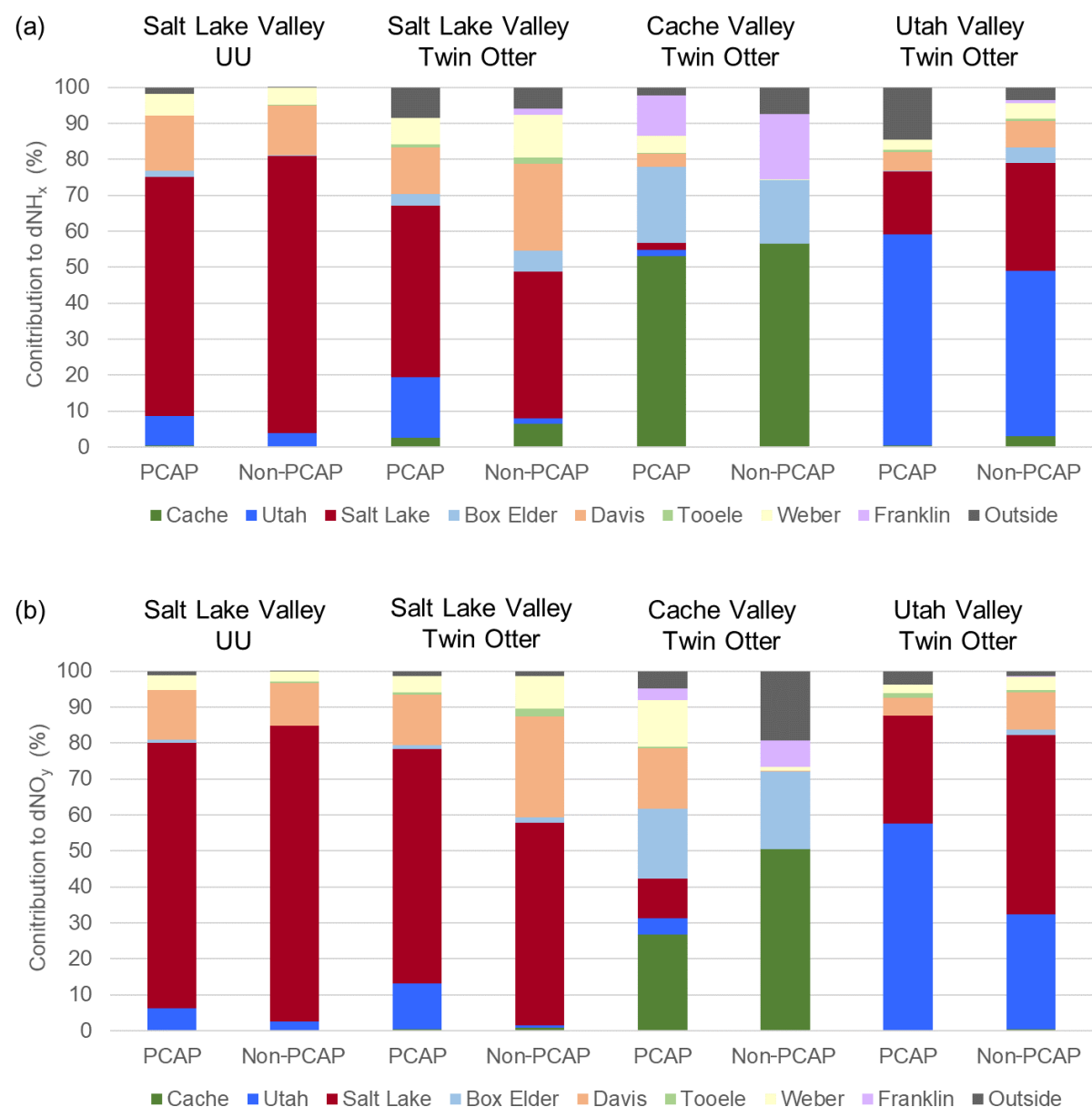

Figure 8. Inter-valley exchange of pollutants: contributions from different counties to (a) $\mathrm{dNH}_{x}$ and (b) $\mathrm{dNO}_{y}$ at the UU (Salt Lake Valley) site and Twin Otter locations in Salt Lake Valley, Cache Valley and Utah Valley. The inter-valley exchange was evaluated by segregating contributions from the footprint model (see contributions map in Fig. 5) into counties of origin for each run of the footprint model (i.e. every 2 min of Twin Otter flight path and every hour for the UU location).

tentially leading to $\mathrm{PM}_{2.5}$ formation in Cache Valley may not be locally emitted but mixed in from other counties.

For Utah Valley, inter-valley exchange seems slightly less important than for Cache Valley, as $58.7 \%$ of $\mathrm{dNH}_{x}$ and $57.6 \%$ of $\mathrm{dNO}_{y}$ originated in Utah County during PCAP periods. Nonetheless, transport from Salt Lake County during PCAP conditions is still significant with contributions of $17.5 \%$ to $\mathrm{dNH}_{x}$ and $29.9 \%$ to $\mathrm{dNO}_{y}$. During nonPCAP conditions the percentage contributions from Salt Lake County to $\mathrm{dNH}_{x}(29.9 \%)$ and $\mathrm{dNO}_{y}(49.8 \%)$ are even higher, although formation of $\mathrm{NH}_{3} \mathrm{NO}_{4}$ is less important as demonstrated in the lower $\mathrm{PM}_{2.5}$ levels observed (Fig. 3).

\section{Conclusions}

Winter air pollution in the Great Salt Lake region has been shown to be mainly linked to the formation of ammonium nitrate aerosol. Understanding the sources of $\mathrm{NH}_{3}$ is key to making reliable predictions of ammonium aerosol forma- tion and identifying the appropriate mitigation strategies for $\mathrm{PM}_{2.5}$. To investigate $\mathrm{NH}_{3}$ emissions in the Great Salt Lake region, we sampled $\mathrm{NH}_{3}$ and $p \mathrm{NH}_{4}$ from a Twin Otter aircraft over the Great Salt Lake region in northern Utah and at selected ground sites.

We found that $\mathrm{NH}_{x}$ (which is equal to $\mathrm{NH}_{3}+p \mathrm{NH}_{4}$ ) was highest in Cache Valley, which can be attributed to the large number of $\mathrm{NH}_{3}$-emitting livestock and poultry operations in the Cache Valley. However, $\mathrm{NH}_{3}$ emissions in the commonly used UDAQ $\mathrm{NH}_{3}$ emission inventory are not significantly larger in Cache Valley than in Salt Lake Valley or Utah Valley, as the measurements would suggest. Using a STILT footprint model approach, our results suggest that in Cache Valley livestock emissions in the UDAQ inventory are underestimated by a factor of approximately 4.5 for January and February 2017, based on the following findings: (1) the factor between modelled and measured $\mathrm{NH}_{x}$ enhancements was 4.4 and (2) total UDAQ $\mathrm{NH}_{3}$ emissions in Cache Valley are lower by a factor of 2.61 compared to emissions estimated in 
the USU inventory. One reason for the discrepancy could be the underestimation of wintertime emissions through the applied monthly profile in the UDAQ emission inventory. This emphasizes the importance of generating year-specific emission factors and temporal profiles that are based on the meteorological conditions of the year for which the inventory is run. Furthermore, our results suggest that in areas with large livestock operations, moving towards facility-based inventories for livestock $\mathrm{NH}_{3}$ emissions can yield better $\mathrm{NH}_{3}$ and $\mathrm{NH}_{x}$ predictions in local or regional air quality models. However, more extensive datasets, which also include summertime measurements, would be needed to evaluate the uncertainties of livestock emissions within inventories in more detail.

Our investigation of the inter-valley exchange during the study period revealed that in Salt Lake Valley around two thirds of $\mathrm{NH}_{x}$ originated within the valley, while $\mathrm{NH}_{x}$ transport from Cache Valley was negligible and therefore did not significantly impact the formation of $\mathrm{PM}_{2.5}$ in Salt Lake Valley. In contrast, the transport of $\mathrm{NH}_{x}$ from Utah Valley can be significant during PCAP period when southerly winds prevail. Furthermore, we found that in Cache Valley a significant fraction $(70 \%)$ of the $\mathrm{NO}_{x}$ potentially leading to $\mathrm{PM}_{2.5}$ formation is not locally emitted and is instead transported from other counties. While nearly $20 \%$ of the $\mathrm{NO}_{y}$ in Cache Valley originated in the adjacent Box Elder County, still $11 \%$ of the Cache Valley $\mathrm{NO}_{y}$ was transported from Salt Lake County, about $50 \mathrm{~km}$ away. Since it was found that the formation of ammonium nitrate in Cache Valley was mostly nitrate limited during the UWFPS campaign, this illustrates the potential effect which regulation of $\mathrm{NO}_{x}$ emissions in Salt Lake County may have on neighbouring regions with higher agricultural $\mathrm{NH}_{3}$ emissions.

Data availability. Data from the UWFPS campaign can be found on the NOAA website at https://www.esrl.noaa.gov/csd/groups/ csd7/measurements/2017uwfps/ (last access: November 2019, NOAA, 2017).

Supplement. The supplement related to this article is available online at: https://doi.org/10.5194/acp-19-15691-2019-supplement.

Author contributions. AM performed the measurements and analysis of airborne $\mathrm{NH}_{3}$ and wrote the paper. JGM provided input at all stages regarding the measurements, analysis and discussion of the results. AF and AMM obtained and analyzed the aircraft based AMS data. DLF, CCW and EEM obtained and analyzed the NOx$\mathrm{CaRD}$ data. $\mathrm{AH}$ and $\mathrm{RM}$ provided the ground site $\mathrm{NH}_{3}$ data. AM performed the model analysis with support from AH and JCL. JCL ran the STILT model, and CP, RM and KM provided the emission inventory data. SSB and MB planned and organized the UWFPS measurement campaign. All authors discussed the results and contributed to the final paper.
Competing interests. The authors declare that they have no conflict of interest.

Acknowledgements. The authors would like to acknowledge the Utah Division of Air Quality for their support and collaboration during the study. We thank the NOAA Aircraft Operations Center for their dedication and professionalism, particularly the pilot, Robert Mitchel, and Jason Clark for skilful navigation in complex terrain and challenging meteorology. We thank Bill Dube for taking the technical lead in instrument installation on the Twin Otter aircraft. We thank Lexie Goldberger for assistance in obtaining the presented aircraft measurements and Joel Thornton for providing input to the project design and comments to the presented paper. Furthermore, we would also like to thank the Utah Water Research Laboratory and the Utah State University Facilities for their support.

Financial support. NOAA acknowledges support for Twin Otter flights from the Utah Division of Air Quality (agreement no. 16049696).

Review statement. This paper was edited by Ashu Dastoor and reviewed by two anonymous referees.

\section{References}

AMoN: Ammonia Monitoring Network, Natl. Atmos. Depos. Program, available at: http://nadp.slh.wisc.edu/amon/, last access: 19 November 2019.

Baek, B. H. and Seppanen, C.: Sparse Modeling Operator Kerner Emissions (SMOKE) Modeling System (Version SMOKE User's Documentation), https://doi.org/10.5281/zenodo.1421403, 2018.

Bahreini, R., Dunlea, E. J., Matthew, B. M., Simons, C., Docherty, K. S., DeCarlo, P. F., Jimenez, J. L., Brock, C. A., and Middlebrook, A. M.: Design and operation of a pressure-controlled inlet for airborne sampling with an aerodynamic aerosol lens, Aerosol Sci. Technol., 42, 465-471, https://doi.org/10.1080/02786820802178514, 2008.

Drewnick, F., Hings, S. S., DeCarlo, P., Jayne, J. T., Gonin, M., Fuhrer, K., Weimer, S., Jimenez, J. L., Demerjian, K. L., Borrmann, S., and Worsnop, D. R.: A new time-of-flight aerosol mass spectrometer (TOF-AMS) - Instrument description and first field deployment, Aerosol Sci. Technol., 39, 637-658, https://doi.org/10.1080/02786820500182040, 2005.

Ellis, R. A., Murphy, J. G., Pattey, E., van Haarlem, R., O’Brien, J. M., and Herndon, S. C.: Characterizing a Quantum Cascade Tunable Infrared Laser Differential Absorption Spectrometer (QC-TILDAS) for measurements of atmospheric ammonia, Atmos. Meas. Tech., 3, 397-406, https://doi.org/10.5194/amt-3397-2010, 2010.

Franchin, A., Fibiger, D. L., Goldberger, L., McDuffie, E. E., Moravek, A., Womack, C. C., Crosman, E. T., Docherty, K. S., Dube, W. P., Hoch, S. W., Lee, B. H., Long, R., Murphy, J. G., Thornton, J. A., Brown, S. S., Baasandorj, M., and Middlebrook, A. M.: Airborne and ground-based observations of ammoniumnitrate-dominated aerosols in a shallow boundary layer during in- 
tense winter pollution episodes in northern Utah, Atmos. Chem. Phys., 18, 17259-17276, https://doi.org/10.5194/acp-18-172592018, 2018.

Fuchs, H., Dubé, W. P., Lerner, B. M., Wagner, N. L., Williams, E. J., and Brown, S. S.: A sensitive and versatile detector for atmospheric $\mathrm{NO}_{2}$ and $\mathrm{NO}_{x}$ based on blue diode laser cavity ring-down spectroscopy, Environ. Sci. Technol., 43, 7831-7836, https://doi.org/10.1021/es902067h, 2009.

Gilliland, A. B., Wyat Appel, K., Pinder, R. W., and Dennis, R. L.: Seasonal $\mathrm{NH}_{3}$ emissions for the continental united states: Inverse model estimation and evaluation, Atmos. Environ., 40, 49864998, https://doi.org/10.1016/j.atmosenv.2005.12.066, 2006.

Hacker, J. M., Chen, D., Bai, M., Ewenz, C., Junkermann, W., Lieff, W., Mcmanus, B., Neininger, B., Sun, J., Coates, T., Denmead, T., Flesch, T., Mcginn, S., and Hill, J.: Using airborne technology to quantify and apportion emissions of $\mathrm{CH}_{4}$ and $\mathrm{NH}_{3}$ from feedlots, Anim. Prod. Sci., 56, 190-203, 2016.

Hammond, I. A., Martin, R. S., Silva, P., and Baasandorj, M.: Wintertime ambient ammonia concentrations in Northern Utah's Urban Valleys, paper A53B-221, 2017 Fall meeting of the Amerian Geophysical Union, New Orleans, LA, USA, 11-15 December, 2017.

HRRR: High-Resolution Rapid Refresh, available at: https:// rapidrefresh.noaa.gov/hrrr/, last access: 18 December, 2017.

Jayne, J. T., Leard, D. C., Zhang, X., Davidovits, P., Smith, K. A., Kolb, C. E., and Worsnop, D. R.: Development of an aerosol mass spectrometer for size and composition analysis of submicron particles, Aerosol Sci. Technol., 33, 49-70, https://doi.org/10.1080/027868200410840, 2000.

Kelly, K. E., Kotchenruther, R., Kuprov, R., and Silcox, G. D.: Receptor model source attributions for Utah's Salt Lake City airshed and the impacts of wintertime secondary ammonium nitrate and ammonium chloride aerosol, J. Air Waste Manag. Assoc., 63, 575-590, https://doi.org/10.1080/10962247.2013.774819, 2013.

Kuprov, R., Eatough, D. J., Cruickshank, T., Olson, N., Cropper, P. M., and Hansen, J. C.: Composition and secondary formation of fine particulate matter in the Salt Lake Valley: Winter 2009, J. Air Waste Manag. Assoc., 64, 957-969, https://doi.org/10.1080/10962247.2014.903878, 2014.

Markovic, M. Z., Vandenboer, T. C., and Murphy, J. G.: Characterization and optimization of an online system for the simultaneous measurement of atmospheric water-soluble constituents in the gas and particle phases, J. Environ. Monit., 14, 1872-1884, https://doi.org/10.1039/c2em00004k, 2012.

McDuffie, E. E., Womack, C. C., Fibiger, D. L., Dube, W. P., Franchin, A., Middlebrook, A. M., Goldberger, L., Lee, B. H., Thornton, J. A., Moravek, A., Murphy, J. G., Baasandorj, M., and Brown, S. S.: On the contribution of nocturnal heterogeneous reactive nitrogen chemistry to particulate matter formation during wintertime pollution events in Northern Utah, Atmos. Chem. Phys., 19, 9287-9308, https://doi.org/10.5194/acp19-9287-2019, 2019.

McQuilling, A. M. and Adams, P. J.: Semi-empirical process-based models for ammonia emissions from beef, swine, and poultry operations in the United States, Atmos. Environ., 120, 127-136, https://doi.org/10.1016/j.atmosenv.2015.08.084, 2015.

Mitchell, L. E., Crosman, E. T., Jacques, A. A., Fasoli, B., LeclairMarzolf, L., Horel, J., Bowling, D. R., Ehleringer, J. R., and Lin, J. C.: Monitoring of greenhouse gases and pollutants across an urban area using a light-rail public transit platform, Atmos. Environ., 187, 9-23, https://doi.org/10.1016/j.atmosenv.2018.05.044, 2018.

Moore, K. D.: Derivation of agricultural gas-phase ammonia emissions and application to the Cache Valley, MS thesis, Utah State University, Logan, UT, 2007.

Moravek, A., Singh, S., Pattey, E., Pelletier, L., and Murphy, J. G.: Measurements and quality control of ammonia eddy covariance fluxes: a new strategy for high-frequency attenuation correction, Atmos. Meas. Tech., 12, 6059-6078, https://doi.org/10.5194/amt-12-6059-2019, 2019.

NOAA: Utah Winter Fine Particulate Study, available at: https:// www.esrl.noaa.gov/csd/groups/csd7/measurements/2017uwfps/ (last access: 17 November 2019), 2017.

Nowak, J. B., Neuman, J. A., Bahreini, R., Middlebrook, A. M., Holloway, J. S., McKeen, S. A., Parrish, D. D., Ryerson, T. B., and Trainer, M.: Ammonia sources in the California South Coast Air Basin and their impact on ammonium nitrate formation, Geophys. Res. Lett., 39, L07804, https://doi.org/10.1029/2012GL051197, 2012.

Pollack, I. B., Lindaas, J., Roscioli, J. R., Agnese, M., Permar, W., Hu, L., and Fischer, E. V.: Evaluation of ambient ammonia measurements from a research aircraft using a closed-path QC-TILDAS operated with active continuous passivation, Atmos. Meas. Tech., 12, 3717-3742, https://doi.org/10.5194/amt12-3717-2019, 2019.

Pozzer, A., Tsimpidi, A. P., Karydis, V. A., de Meij, A., and Lelieveld, J.: Impact of agricultural emission reductions on fine-particulate matter and public health, Atmos. Chem. Phys., 17, 12813-12826, https://doi.org/10.5194/acp-17-12813-2017, 2017.

Silcox, G. D., Kelly, K. E., Crosman, E. T., Whiteman, C. D., and Allen, B. L.: Wintertime $\mathrm{PM}_{2.5}$ concentrations during persistent, multi-day cold-air pools in a mountain valley, Atmos. Environ., 46, 17-24, https://doi.org/10.1016/j.atmosenv.2011.10.041, 2012.

Skamarock, W. C. and Klemp, J. B.: A time-split nonhydrostatic atmospheric model for weather research and forecasting applications, J. Comput. Phys., 227, 3465-3485, https://doi.org/10.1016/j.jcp.2007.01.037, 2008.

Sun, K., Tao, L., Miller, D. J., Pan, D., Golston, L. M., Zondlo, M. A., Griffin, R. J., Wallace, H. W., Leong, Y. J., Yang, M. M., Zhang, Y., Mauzerall, D. L., and Zhu, T.: Vehicle Emissions as an Important Urban Ammonia Source in the United States and China, Environ. Sci. Technol., 51, 2472-2481, https://doi.org/10.1021/acs.est.6b02805, 2017.

USGS: United States Geological Survey Elevation and Terrain Data, available at: https://gis.utah.gov/data/ elevation-and-terrain/, last access: 11 October, 2017.

UWFPS: 2017 Utah Winter Fine Particulate Study Final Report?; submitted to the Utah Division of Air Quality (UDAQ), available at: https://documents.deq.utah.gov/air-quality/ planning/technical-analysis/research/northern-utah-airpollution/ utah-winter-fine-particulate-study/DAQ-2018-004037.pdf (last access: 17 November 2019), 2018.

Van Damme, M., Clarisse, L., Whitburn, S., Hadji-Lazaro, J., Hurtmans, D., Clerbaux, C., and Coheur, P. F.: Industrial and agricultural ammonia point sources exposed, Nature, 564, 99-103, https://doi.org/10.1038/s41586-018-0747-1, 2018. 
Washenfelder, R. A., Wagner, N. L., Dube, W. P., and Brown, S. S.: Measurement of atmospheric ozone by cavity ringdown spectroscopy, Environ. Sci. Technol., 45, 2938-2944, https://doi.org/10.1021/es103340u, 2011.

Whitehead, J. D., Twigg, M., Famulari, D., Nemitz, E., Sutton, M. A., Gallagher, M. W., and Fowler, D.: Evaluation of Laser Absorption Spectroscopic Techniques for Eddy Covariance Flux Measurements of Ammonia, Environ. Sci. Technol., 42, 20412046, https://doi.org/10.1021/es071596u, 2008.

Whiteman, C. D., Hoch, S. W., Horel, J. D., and Charland, A.: Relationship between particulate air pollution and meteorological variables in Utah's Salt Lake Valley, Atmos. Environ., 94, 742753, https://doi.org/10.1016/j.atmosenv.2014.06.012, 2014.

WHO: Ambient (outdoor) air quality and health, World Health Organization, available at: http://www.who.int/mediacentre/ factsheets/fs313/en/ (last access: 17 November 2019, 2016.

Wild, R. J., Edwards, P. M., Dubé, W. P., Baumann, K., Edgerton, E. S., Quinn, P. K., Roberts, J. M., Rollins, A. W., Veres, P. R., Warneke, C., Williams, E. J., Yuan, B., and Brown, S. S.: A measurement of total reactive nitrogen, $\mathrm{NO}_{y}$, together with $\mathrm{NO}_{2}$, $\mathrm{NO}$, and $\mathrm{O}_{3}$ via cavity ring-down spectroscopy, Environ. Sci. Technol., 48, 9609-9615, https://doi.org/10.1021/es501896w, 2014.
Womack, C. C., McDuffie, E. E., Edwards, P. M., Bares, R., Gouw, J. A. A., Docherty, K. S., Dubé, W. P., Fibiger, D. L., Franchin, A., Gilman, J. B., Goldberger, L., Lee, B. H., Lin, J. C., Long, R., Middlebrook, A. M., Millet, D. B., Moravek, A., Murphy, J. G., Quinn, P. K., Riedel, T. P., Roberts, J. M., Thornton, J. A., Valin, L. C., Veres, P. R., Whitehill, A. R., Wild, R. J., Warneke, C., Yuan, B., Baasandorj, M., and Brown, S. S.: An Odd Oxygen Framework for Wintertime Ammonium Nitrate Aerosol Pollution in Urban Areas: $\mathrm{NO}_{x}$ and VOC Control as Mitigation Strategies, Geophys. Res. Lett., 46, 4971-4979, https://doi.org/10.1029/2019GL082028, 2019.

Zhang, L., Chen, Y., Zhao, Y., Henze, D. K., Zhu, L., Song, Y., Paulot, F., Liu, X., Pan, Y., Lin, Y., and Huang, B.: Agricultural ammonia emissions in China: reconciling bottom-up and top-down estimates, Atmos. Chem. Phys., 18, 339-355, https://doi.org/10.5194/acp-18-339-2018, 2018.

Zhao, Z. Q., Bai, Z. H., Winiwarter, W., Kiesewetter, G., Heyes, C., and Ma, L.: Mitigating ammonia emission from agriculture reduces $\mathrm{PM}_{2.5}$ pollution in the Hai River Basin in China, Sci. Total Environ., 609, 1152-1160, https://doi.org/10.1016/j.scitotenv.2017.07.240, 2017. 